\title{
Article \\ Approaches towards Land Valuation and Land Pricing under the Influence of Geo-Climate Change
}

\author{
Josef Slaboch * and Michal Malý
}

Citation: Slaboch, J.; Malý, M. Approaches towards Land Valuation and Land Pricing under the Influence of Geo-Climate Change. Agriculture 2022, 12, 63. https://doi.org/ 10.3390 /agriculture 12010063

Received: 2 November 2021

Accepted: 1 January 2022

Published: 5 January 2022

Publisher's Note: MDPI stays neutral with regard to jurisdictional claims in published maps and institutional affiliations.

Copyright: (C) 2022 by the authors. Licensee MDPI, Basel, Switzerland. This article is an open access article distributed under the terms and conditions of the Creative Commons Attribution (CC BY) license (https:// creativecommons.org/licenses/by/ $4.0 /)$.
Department of Economics, Faculty of Economics and Management, Czech University of Life Sciences Prague, Kamýcká 192, 16500 Prague, Czech Republic; maly@pef.czu.cz

* Correspondence: jslaboch@pef.czu.cz; Tel.: +420-22438-2843

\begin{abstract}
The Czech Republic is more or less unique in its dual system (official and market price) of agricultural land prices. In the case of the market price, there are several studies and approaches that assess the impact of individual variables on the market price of land. If we focus on the official price of land, its value in the Czech Republic is influenced by the evaluated soil ecological unit (ESEU) price. The ESEU price expresses the production potential of the land on the basis of soil quality indicators, which include the climatic region, the main soil unit, slope and exposure and, last but not least, the depth of the soil profile and skeletonisation. Climate change also means that the current values of the definition (e.g., for a climatic region, this refers to the average temperature or average precipitation) do not correspond to reality. No studies have looked in detail at the impact of soil quality indicators or climate change on the price of ESEUs. New and more accurate measurements of soil characteristics are increasing the number of ESEU codes, and prices have not yet been set for some codes. For this reason, we proposed the use of a hedonic method to determine shadow prices, which reflect the intensity and direction of the effect of each input variable on the price of an ESEU. A heteroscedastic corrected linear regression model was used to determine the coefficients, which presents in detail the effect of all included parameters on the final price of an ESEU in the results section. From the results, it was obvious that the shadow price coefficients themselves corresponded to basic generally accepted assumptions regarding the direction of effect. In the conditions of the Czech Republic, a significant influence on the price of an ESEU was mainly the slope with exposure and the depth of the soil profile with skeletonisation. These factors affected the productive capacity of the soil, which, in turn, translated into lower profitability of agricultural entities. The high explanatory ability of the hedonic model, with a high parametric significance for most of the used variables, was an important factor determining the robustness of the model as a repricing tool. The model set according to the prices of the applicable price decree can be used to set the prices of new or not-yet-valued ESEU codes under the conditions in the Czech Republic, or shadow prices can be used during climatic changes in the event of the transfer of the given soil unit to another climate region according to the general specification. It is therefore an important tool for the needs of the public administration.
\end{abstract}

Keywords: land price; soil; hedonic price; evaluated soil ecological unit; geo-climate change

\section{Introduction}

Soil is probably the most complex of all geological materials. It consists of combinations of mineral and organic components in solid, aqueous and gaseous forms, which are organised into loose, porous, horizontal, vegetation-bearing material that is constantly changing. Soil is formed as a consequence of a complex series of interactions and reverse connections between the lithosphere, hydrosphere, atmosphere and biosphere [1]. Soil, as one of the factors of production and a basic means of agricultural production, requires our protection from the perspective of maintaining continuous production. The loss of high-quality agricultural land is perceived as an extensive problem in both developing and developed economies. The main threats include water and wind erosion [2]. Soil 
erosion can lead to lower soil fertility, root zone reduction and nutrient loss [3]. Soil is a very specific production factor, as its properties do not allow for reproduction or relocation, and it has a limited extent. For these reasons, it is very important to protect this source of production for future generations [4].

A very sensitive aspect of soil is certainly the determination of an appropriate price of soil (especially agricultural). Globally, various methodological approaches and valuation systems are used for this purpose, which can differ significantly, especially depending on the definition of the qualitative parameters of the soil, but also the mechanism for determining the final price of the land. In the European area, two basic directions can generally be seen regarding land valuation, which can be characterised as maximally simplifying mechanisms (usually based only on the market price given by market supply and demand) and systems which, in contrast, take into account a wide range of soil properties/effects. Scientific works thus offer a possible comparison, whereby from the perspective of the direction of future agricultural policy and the growing importance of agricultural land for food security, the expansion of multi-criteria land valuation systems is likely; see, for example, [5-10].

According to information from Eurostat, it is possible to perform a very simple comparison of agricultural land prices based on data on the average market price of land. From the aforementioned perspective, the highest prices are in the Netherlands (approximately 70,000 EUR/ha), Italy and Denmark (approximately 30-40,000 EUR/ha), while the lowest prices are recorded in Bulgaria (approximately $2000 \mathrm{EUR} / \mathrm{ha}$ ) and Romania (approximately $1500 \mathrm{EUR} / \mathrm{ha}$ ). When evaluating the Central European region, there is considerable heterogeneity in this sense, both in the approach to determining land prices and in the land price level itself, whereby the only common characteristic is probably the absolutely fastest land price growth dynamic in Europe. Specifically, it is very interesting to observe the price development and comparison in Germany, Poland and the Czech Republic. In Germany, according to information from Eurostat, the average land price does not exceed 20,000 EUR/ha, but there is considerable differentiation between the western and eastern parts, whereby development trends also manifest themselves differently in specific areas; see, for example, [11]. The Polish land valuation system is closer to the system used in the Czech Republic, but in terms of amounts, the price of agricultural land is higher; according to information from Eurostat, it fluctuates between 9000 and 11,000 EUR/ha. At the same time, however, the Polish legislative system is the least inclined towards the liberal market, and there are various restrictions in the land market, which cause a different development from EU trends; see, for example, [12]. The Czech Republic uses a dual system of land valuation through the market price of land and the official price of land based on evaluated soil ecological units (ESEUs). Thus, ESEUs are used to determine the official land price, for the valuation of which, only the following factors are decisive: climatic region, main soil unit, the combination of slope and exposure and the combination of soil profile depth and skeletality. The Czech dual system, which separates the market price of land from the artificially defined official land price, is more or less unique (probably comparable only with the Slovak Republic and partly with Poland), but many works point out the usefulness of the established mechanism, particularly from the perspective of the increasingly popular multi-criteria soil effect rating system. The method of land valuation on the basis of defined evaluated soil ecological units brings an ability to pragmatically evaluate the soil's production potential, which is very desirable when taking into account geoclimatic changes. In a value-based comparison of European prices, it is necessary to state that the market price of land has recorded a significant increase in the last decade, and currently fluctuates between 6000 and 10,000 EUR/ha.

In recent years, the topic of changing climatic conditions around the world is much discussed. In Indonesia, for example, climate change is leading to the updating of agroclimatic maps, primarily the updating and specification of total precipitation [13]. Similarly, for example in India, there has been an analysis of annual trends, as well as maximum and minimum temperatures in selected regions. The results show an increasing temperature 
trend over the analysed period [14]. Another important effect of climate change is the difference in the characteristics of seasonal precipitation, which can change crop planting conditions or sowing procedures [15]. Similarly, for example in Sweden, the effect of climate change on the production of basic annual crops (barley, wheat, corn, oats) is being evaluated. The results show that, at certain geographical latitudes (between 55 and $64^{\circ}$ ), climate change can have a positive effect on crop production [16]. Climate change itself, or more precisely potential extreme weather events, can also lead to a lower yield from the planted crops, which can negatively affect farmers [17].

From the perspective of climate change under the conditions in the Czech Republic, a study was published by [18], which pointed out a major shift in agroclimatic zones in the Czech Republic between 1961 and 2019. The method used for the agroclimatic zoning used daily high-resolution $(0.5 \mathrm{~km} \times 0.5 \mathrm{~km})$ climate data collected from 268 climatological and 787 rainfall stations. Climate information was combined with soil and terrain data of the same resolution. A set of seven agroclimatic indicators made it possible to estimate the speed of changes in agroclimatic conditions in the period of 1961-2019, including changes in air temperature, global radiation, drought, risk of frost and snow cover. These indicators are relevant for all main crops and agroclimatic zoning, and take into account local soil and slope conditions. The study clearly points out fundamental shifts in the type and extent of agroclimatic zones in the years 1961-2000 and 2000-2019, which led to the occurrence of completely new combinations of agroclimatic indicators.

Several studies [19-23] were conducted on the topic of agricultural land prices, but they focused mainly on the market price. For example, [24] confirmed the hypothesis of the relationship between the market value of a parcel and its area and the availability of hardened access roads using the hedonic method. They did not confirm the relationship of the market value of land.

Other studies focused on the influence of non-production functions on agricultural land and their impact on land prices (for example, $[25,26]$ ), or on the influence of agriculture on the market price of land in urban areas. For example, [27] highlighted the positive and negative externalities of agricultural land. Using the hedonic price model, they pointed out that agricultural open space increases the value of nearby residential properties, but large-scale livestock farming and mushroom production have negative impacts on price. The uniqueness of this study lies in the application of the hedonic method to determine the effect of land characteristics on the price of an ESEU, which is then reflected in the official land price, thus affecting the amount of the real estate tax paid.

Different methods are used to determine the tax liability on agricultural land in different states. In some countries, the official land price is used to calculate the tax liability, which is generally lower than the market price. The official land price is used, for example, in Austria, Belgium, Denmark, Latvia, Switzerland, the USA or the Czech Republic. A comparison of the different countries also shows that the obligations of the different entities differ in terms of the calculation methodology, the rates applied or what is actually subject to taxation. Exemptions from land or agricultural property tax are applied, for example, in Australia, Canada (some provinces), Finland, Italy, Japan, Slovenia, Sweden or the United Kingdom. On the other hand, in some countries, only buildings used for agricultural production are exempt or the tax is significantly reduced; this applies, for example, to France, Hungary, Lithuania, Norway and Poland [28].

From the perspective of individual countries, this system is unique; it is used essentially only in the Czech Republic and Slovakia. A system set in this way is specific primarily by its detailed description of soil properties in the given region. Since the 1990s, the evidence in the database of evaluated eco-economic units (ESEUs) has been regularly updated. The intensive cultivation of widely spaced crops, particularly on extended, predominantly sloping plots, led to the degradation of soil properties due to erosion. Updating the ESEUs makes it possible to detect these changes and to quantify them using differences in land price [29]. The official price of land is determined by the applicable price decree (currently Decree no. 441/2013 Coll.); these decrees are updated in certain cycles. For example, [30] 
considered price development. The results of the study show an average ESEU price increase of 36\% in the assessed locality between 2002 and 2019. At the same time, in the selected area, there is a reduction in the quantity and quality of agricultural land (usually due to urbanisation for the benefit of municipalities or cities). If this trend continues in the future, there may be a considerable loss of agricultural land, which could lead to problems in sustainable agriculture or a potential shortage of food resources.

Based on the above characteristics, it can be stated that the land valuation system using the ESEU brings several advantages and disadvantages, which corresponds to the design of this study. The basic theoretical framework was based on the concept of a model that would allow for the expression of the so-called shadow land prices, which should correspond as best as possible to the real level of exhaustively determined prices of the official land price system. In this form, the main goal of this study can be defined as determining the shadow prices of the input parameters characterising soil quality under the conditions in the Czech Republic using the hedonic method.

The specified model is designed based on a hedonic approach using exhaustively defined determinants of ESEUs and allows not only to determine shadow land prices but is also usable in practice for revaluation over time or valuation of newly created parts of land. As mentioned, there are price adjustments over time, which are reflected in the newly set official price of land. However, this is set at a significantly different value without adequate justification. Therefore, in the following parts of the article, separate models are discussed for the four basic time periods defined by the partial valuation decrees. The purpose was to compare the mechanism of revaluation over time and determine the differences in the intensity of the determinants of the final price, which was contained in another goal of the paper, i.e., to evaluate the development of the official prices of agricultural land under the conditions in the Czech Republic for the period of 1997-2021 on the basis of the applicable price decrees.

The achieved results can be considered a relatively important tool for state management. The generated models aimed to show some shortcomings in the evaluation of the intensity and significance of the units used in the current system of exhaustive determination of the official price of land (see research questions RQ1 and RQ2). Last but not least, a sufficient explanatory ability was required from the basic model so that it can be used in practice for further necessary revaluation and valuation of newly created land areas (see research question RQ3).

This study is innovative in terms of assessing the influence of soil quality characteristics on the price of an ESEU. The purpose was to have a tool that, based on the discrimination of soil quality characteristics, can be universally used for the rapid determination of the price of an ESEU. Due to climate change, it is also important to note the fact that the current values of the definition (e.g., for a climatic region this refers to the average temperature or average precipitation) do not correspond to reality. The main reasons for expanding the number of codes are to take into account the degradation changes, fundamental changes in soil hydromorphism, obtainment of information regarding ESEUs for plots where ESEUs were not previously determined, commencement of comprehensive land modification, etc. The above shows the need to react quickly and flexibly to changes that affect the production potential of agricultural land and to set the price of an ESEU adequately on the basis of these changes. For these reasons, the article is very topical and can also be a suitable tool for use in practice in the context of the rapid adaptation and determination of prices for tax purposes.

\section{Materials and Methods}

The following data were used to meet the stated objectives of the study. The quality of the agricultural land fund in the Czech Republic was assessed via a valuation system based on the rating of ecologically productive land. This system was introduced in the years 1960-1980 after a comprehensive survey of agricultural soil. This survey provided comprehensive information on the quality of agricultural land, and the price of agricultural 
land plots derived from their production capacity. On the basis of the data obtained in this way, an ESEU system was created, which expresses the production potential of a given soil area.

The actual determination of the ESEU price is performed using the yield method. At this point, it is important to state the procedure by which the GARE (gross annual rent effect), which is the basis for determining the production potential of the given soil and, subsequently, also the price itself, is calculated. The official price is then used, for example, to determine the real estate (agricultural land) tax base or ascertain the price of the land if it is expropriated for public purposes or when trading land during comprehensive land modifications [31].

The GARE calculation for arable land is performed according to the following formula:

$$
\text { GAREar }=(P P P-N P P) * \text { Kots }
$$

where $P P P$ is the parameterised production price set as the corrected yield of main agricultural crops (wheat, spring barley, winter barley, corn for grain, rapeseed, poppy, sugar beet, corn silage and alfalfa) for individual ESEUs, NPP is the normative cost per parameterised production and Kots is a dimensionless number arising from the percentual representation of individual crops in the given valuation structure.

The official land price for agricultural land is calculated according to the following formula:

$$
\text { Land price }(\text { official })=B A L P+\frac{G A R E * D}{U}
$$

where $B A L P$ is the basic agricultural land price, GARE is the gross annual rent effect, $D$ is the total proportion of untaxed crop production and $U$ is the capitalisation (interest) rate. The complete system is described in more detail in [32].

From the above, it is clear that the eventual determination of the price of an ESEU (which has not yet been valued) is very challenging and tedious. For this reason, we intended to develop a workable model based on the data already available in the individual price decrees, which could be used to determine the price of the newly defined ESEU. For the purposes of this article, ESEU price decrees were selected from 1997, 2002, 2008 and 2013 (Decree no. 441/2013 Coll). Research questions (RQs) were set to test the evolution of official prices and the possibility of the shadow pricing of input parameters.

RQ1-In the analysed period of 1997-2021, was there an average increase in ESEU prices of more than $20 \%$ ?

RQ2-In the analysed period of 1977-2021, was there an increase in the number of ESEUs of more than $5 \%$ ?

Index analysis was used to analyse the development of prices of individual ESEU codes; it is the calculation of a chain and basic index for applicable and valued codes within individual price decrees. The chain and basic index were calculated according to standard procedures. Furthermore, basic descriptive statistics (average, minimum, maximum) were applied for the evaluation of the data set. As the price decrees were issued over a longer period of time, the attempt here was to highlight how ESEU prices changed within each decree.

RQ3 - Did the econometric model with a hedonic approach for determining the ESEU price have an explanatory ability $\left(\mathrm{R}^{2}\right)$ of more than 0.85 ?

The applicable decree from 2013 contains 2172 relevant codes. The ESEU code itself is expressed using a five-digit number. This is the basic mapping and valuation unit of the rating system. The first digit in the code indicates the affiliation to the given climate region (0-9). A climate region covers a territory with similar climatic conditions for plant growth (average annual temperature, sum of temperatures, average precipitation, probability of dry growing seasons and guaranteed moisture in a growing season). The second and third digits indicate the affiliation to the main soil unit (0-78), as per the classification system. The main soil unit is a synthetic agronomised unit, which is characterised by the purposeful 
grouping together of genetic soil types, subtypes, degree of hydromorphism and local relief. The fourth digit indicates a combination of slope and exposure (0-9), and the fifth digit (0-9) stands for a combination of soil profile depth and skeletality (for more details see Table 1).

Table 1. Detailed specifications of the variables in the model.

\begin{tabular}{|c|c|}
\hline Dummy Variable & Specifications \\
\hline K1 & Climate region 1 -warm, dry \\
\hline $\mathrm{K} 2$ & Climate region $2-$ warm, slightly dry \\
\hline K3 & Climate region 3-warm, slightly moist \\
\hline $\mathrm{K} 4$ & Climate region 4 -slightly warm, dry \\
\hline K5 & Climate region 5-slightly warm, slightly humid \\
\hline K6 & Climate region 6-slightly warm, warm, very humid \\
\hline K7 & Climate region 7—slightly warm, humid \\
\hline K8 & Climate region 8 -slightly cold, humid \\
\hline K9 & Climate region 9 - cold, moist \\
\hline SDR1 & Land slope: $3-7^{\circ}$, exposition: without exposition \\
\hline SDR2-A & Land slope: $3-7^{\circ}$, exposition: south (K:0-5) \\
\hline SDR2-B & Land slope: $3-7^{\circ}$, exposition: south, east, west (K:6-9) \\
\hline SDR3-A & Land slope: $3-7^{\circ}$, exposition: north (K:6-9) \\
\hline SDR3-B & Land slope: $3-7^{\circ}$, exposition: north, east, west (K:0-5) \\
\hline SDR4-A & Land slope: $7-12^{\circ}$, exposition: south (K:0-5) \\
\hline SDR4-B & Land slope: $7-12^{\circ}$, exposition: south, east, west (K:6-9) \\
\hline SDR5-A & Land slope: $7-12^{\circ}$, exposition: north (K:6-9) \\
\hline SDR5-B & Land slope: $7-12^{\circ}$, exposition: north, east, west (K:0-5) \\
\hline SDR6-A & Land slope: $12-17^{\circ}$, exposition: south (K:0-5) \\
\hline SDR6-B & Land slope: $12-17^{\circ}$, exposition: south, east, west (K:6-9) \\
\hline SDR7-A & Land slope: $12-17^{\circ}$, exposition: north (K:6-9) \\
\hline SDR7-B & Land slope: $12-17^{\circ}$, exposition: north, east, west $(\mathrm{K}: 0-5)$ \\
\hline SDR8-A & Land slope: $17-25^{\circ}$, exposition: south (K:0-5) \\
\hline SDR8-B & Land slope: $17-25^{\circ}$, exposition: south, east, west (K:6-9) \\
\hline SDR9-A & Land slope: $17-25^{\circ}$, exposition: north (K:6-9) \\
\hline SDR9-B & Land slope: $17-25^{\circ}$, exposition: north, east, west $(\mathrm{K}: 0-5)$ \\
\hline SDRH1 & $\begin{array}{c}\text { Depth of soil profile: } 30 \mathrm{~cm} \text { or more, skeletality: not skeletal to } \\
\text { weakly skeletal }\end{array}$ \\
\hline SDRH2 & Depth of soil profile: $60 \mathrm{~cm}$ or more, skeletality: weakly skeletal \\
\hline SDRH3 & Depth of soil profile: $60 \mathrm{~cm}$ or more, skeletality: moderately skeletal \\
\hline SDRH4 & Depth of soil profile: $30 \mathrm{~cm}$ or more, skeletality: moderately skeletal \\
\hline SDRH5 & Depth of soil profile: less than $30 \mathrm{~cm}$, skeletality: weakly skeletal \\
\hline SDRH6 & Depth of soil profile: less than $30 \mathrm{~cm}$, skeletality: moderately skeletal \\
\hline SDRH7 & Depth of soil profile: $30 \mathrm{~cm}$ or more, skeletality: weakly skeletal * \\
\hline SDRH8 & Depth of soil profile: $30-60 \mathrm{~cm}$, skeletality: strongly skeletal \\
\hline SDRH9 & Depth of soil profile: $30-60 \mathrm{~cm}$, skeletality: moderately skeletal \\
\hline D_2 till D_78 & Dummies for each main soil unit \\
\hline
\end{tabular}

Note: * applies to soil units with a land slope above 12 degrees (soil unit 40, 41). Source: own specification based on Decree no. 441/2013 Coll. 
To determine the shadow prices of input variables, the original methodology from a publication by [33] was used and slightly modified, where a heteroscedastic corrected linear regression model was used for the estimate, similarly to other European studies; see, for example, [34]. The concept and estimation of the model met the standard specification and stochastic assumptions, i.e., the estimation of the model (while respecting the heteroscedastic correction) can be considered fully verified.

The ESEU codes were deciphered into individual input parameters (climate region, main soil unit, slope, exposure, soil profile depth and skeletality). The modification of the variables for the calculation of shadow prices compared with the original model consisted of a more detailed arrangement of the combined code indicating slope and exposure, whereby a division of exposures for climate regions $0-5$ and 6-9 was added. Gretl software was used to estimate the individual parameters.

The definitions of the variables in the model are as follows:

$$
Y i=f(K, S D R, S D R H, D)
$$

where $Y i$ is the ESEU price $\left(\mathrm{CZK} / \mathrm{m}^{2}\right), K$ is the vector dummy of variables for climate regions, $S D R$ is the vector dummy of variables for the combined code indicating the slope and exposure, SDRH represents the vector dummy of variables for the combined code indicating the soil profile depth and skeletality and $D$ is the vector dummy of variables defining the main soil unit. The exact specifications of the individual input variables are set forth in Table 1. Compared with the methodology mentioned in the article by [33], there was a better specification for the SDR combined code, where, for practical purposes, worsening variables in terms of exposure were defined within the scope of climate regions $0-5$ and 6-9. In climate regions $0-5$, southern exposure was regarded as worsening, while in contrast, for climate regions 6-9, northern exposure was regarded as worsening.

\section{Results and Discussions}

This section is divided into two parts. The first part first discusses the evolution of the prices of each ESEU code using descriptive statistics. In the second part of this section, models for individual pricing decrees are presented, including shadow prices for individual input parameters.

\subsection{ESEU Price Development for the Period 1997-2021}

The first part of this results presentation is focused on the index analysis for monitoring the development of the prices of individual ESEUs in the analysed years of 1997-2021. A change in the number of codes gradually took place in individual price decrees, which was evident during the calculation of the basic index (2013/1997), where for some codes, given the non-existence of the price, the given index could not be calculated (see Table 2 for more details). In 1997, a large number of codes were not listed or valued in the decree. A more detailed mapping of ESEUs in the Czech Republic therefore gradually led to an expansion of the number of codes from 1818 in 1997 to the current number of 2172 in 2013. The main reasons for the expansion of the number of codes are taking into account degradation changes, basic changes in soil hydromorphism, the discovery of information regarding ESEUs for plots where ESEUs were not previously determined, the commencement of comprehensive land modifications, demonstrably incorrect determination of ESEUs on the basis of existing materials or the need to supplement and refine the national database [35]. The descriptive statistics showed an increase in the average price in the analysed set from 3.37 CZK $/ \mathrm{m}^{2}$ to a level of $4.93 \mathrm{CZK} / \mathrm{m}^{2}$. There was also an evident increase in the minimum and maximum ESEU code price values. Ref. [30] also arrived at an increase in ESEU prices under the conditions in the Czech Republic. 
Table 2. Basic descriptive statistics of the evaluated data set (based on decrees).

\begin{tabular}{ccccc}
\hline Decree & $\mathbf{N}$ & Average $\left(\mathbf{C Z K} / \mathbf{m}^{\mathbf{2}}\right)$ & Min $\left(\mathbf{C Z K} / \mathbf{m}^{\mathbf{2}}\right)$ & Max $\left(\mathbf{C Z K} / \mathbf{m}^{\mathbf{2}}\right)$ \\
\hline Decree 1997 & 1818 & 3.37 & 0.50 & 13.50 \\
\hline Decree 2002 & 2199 & 3.55 & 0.70 & 14.81 \\
\hline Decree 2008 & 2199 & 4.28 & 1.00 & 17.25 \\
\hline Decree 2013 & 2172 & 4.93 & 1.15 & 19.79 \\
\hline Source: own calculations (current exchange rate EUR 1 = CZK 25.67, 30 November 2021).
\end{tabular}

Figure 1 below shows the development of the average price of ESEU codes in the given climate region (in $\mathrm{CZK} / \mathrm{m}^{2}$ ). It was evident that the highest average price was in climate region 3 , which is the most suitable for crop cultivation in terms of climatic conditions. In contrast, the worst off were climate regions 8 and 9 in which there were low average temperatures with a high total annual precipitation value. The average ESEU prices in these two climate regions were $1.99 \mathrm{CZK} / \mathrm{m}^{2}$ and $1.59 \mathrm{CZK} / \mathrm{m}^{2}$.

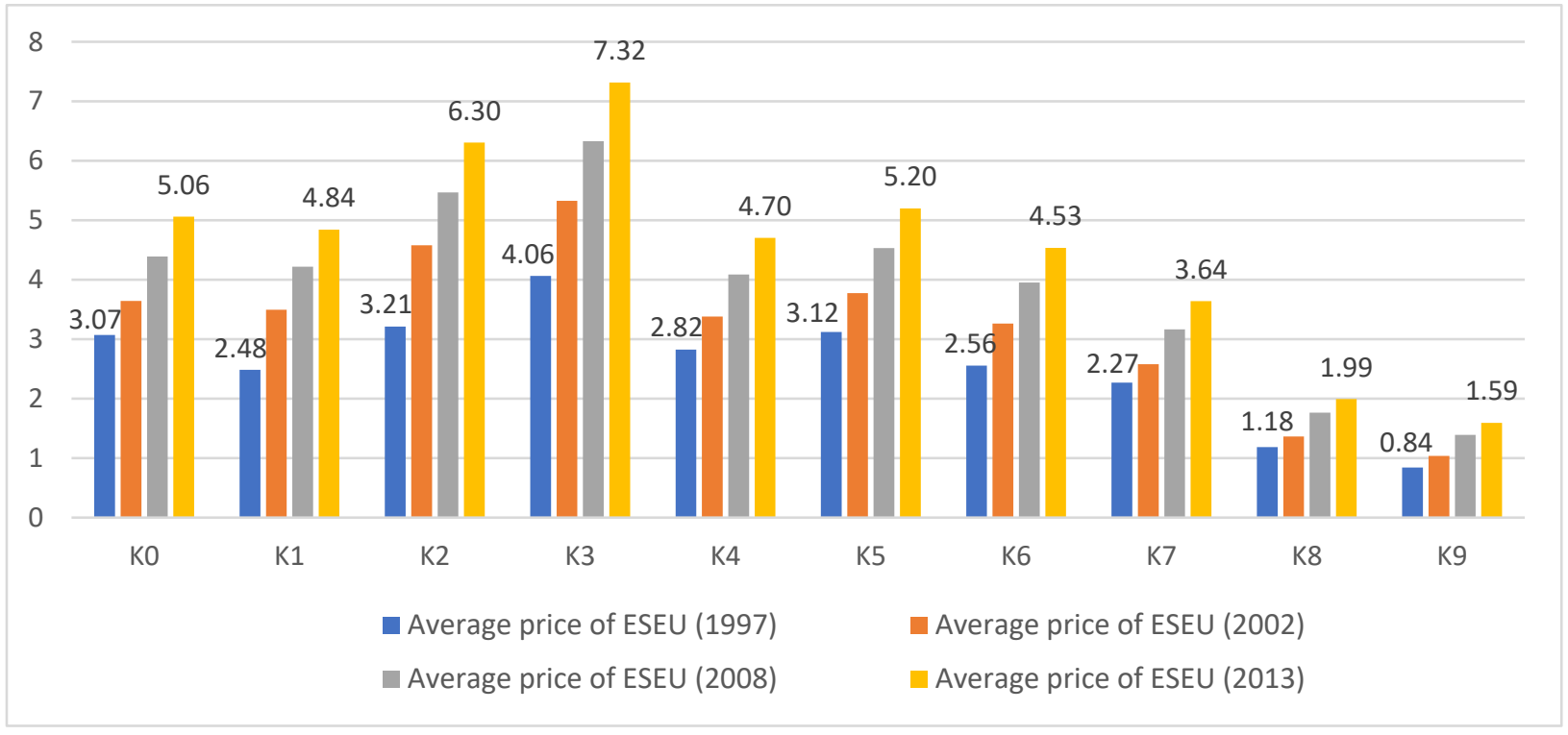

Figure 1. Development of the average ESEU prices by climate region $\left(\mathrm{CZK} / \mathrm{m}^{2}\right)$.

The graph below (Figure 2) shows the climatic regionalisation of the Czech Republic. The individual climatic regions are listed according to their distribution. Despite the fact that the Czech Republic is a small country with an area of $78,000 \mathrm{~km}^{2}$, it is clear, that it is possible to distinguish 10 climate regions. In terms of production possibilities, the ideal climate region is region 3 , which is defined as warm and slightly humid. This climate region is located mainly in the eastern part of Bohemia and central Moravia. On the other hand, climatic regions 8 and 9 are the least suitable and are mainly located at higher altitudes. These areas are not suitable for growing agricultural commodities.

For the purpose of comparison, it is also useful to refer to Figure 3 below, which shows the average official land price in each cadastral area. When comparing the price levels with the map of climatic regions, it can be seen that the average prices follow them to some extent. The highest average prices can be seen in climate regions 2 and 3, where they exceed CZK $10 / \mathrm{m}^{2}$. In contrast to conventional soil surveys, ESEUs also allow for an assessment of the site conditions; all this is aimed at determining the economic value of the site. This can then quantify, for example, the different prices of a plot with a north-facing slope compared with, say, a south-facing slope. This data is then used to determine the average official ESEU price per cadastral area and to levy the land tax. 


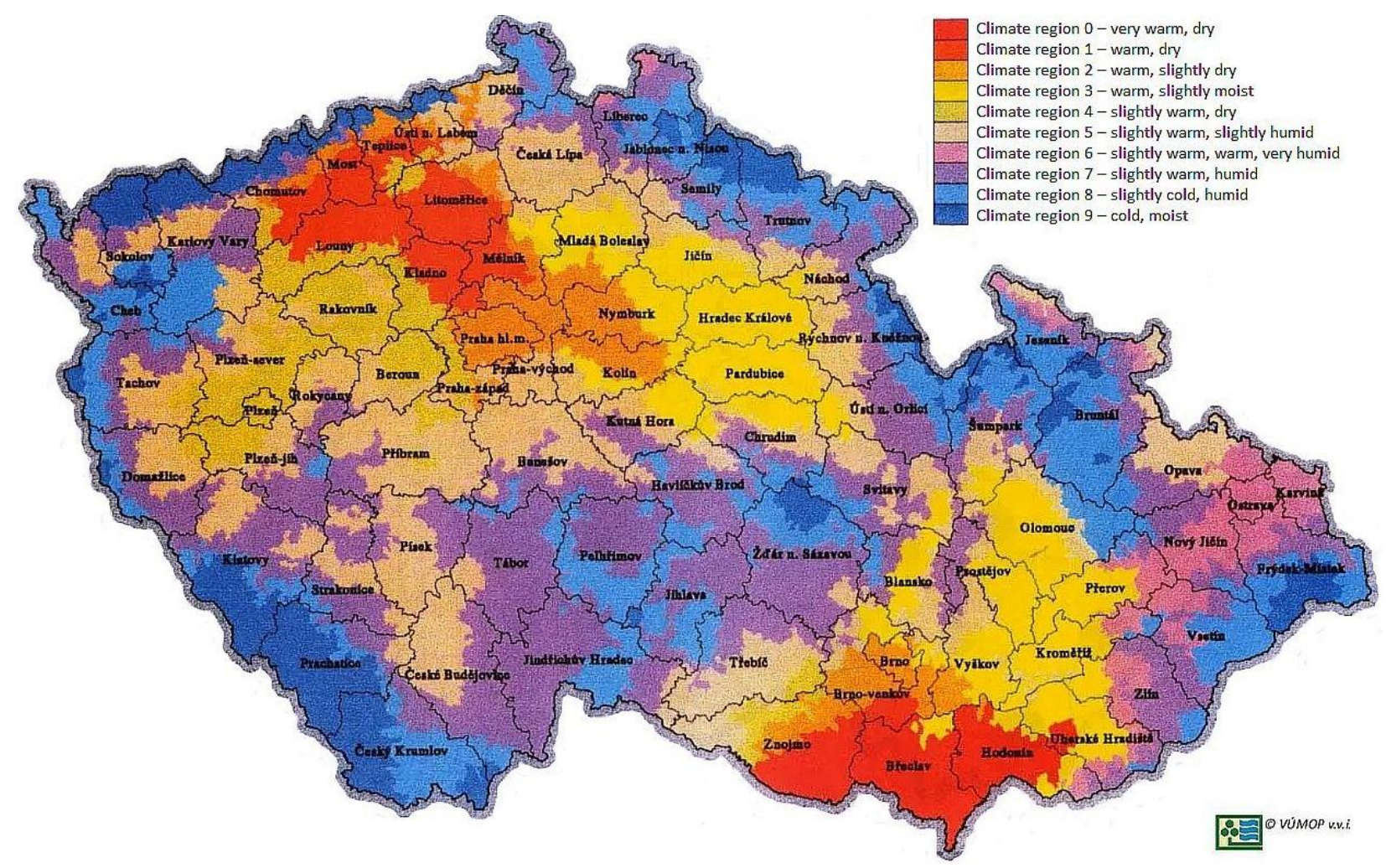

Figure 2. Climate regions in the Czech Republic.

Average price of agricultural land by cadastral territory

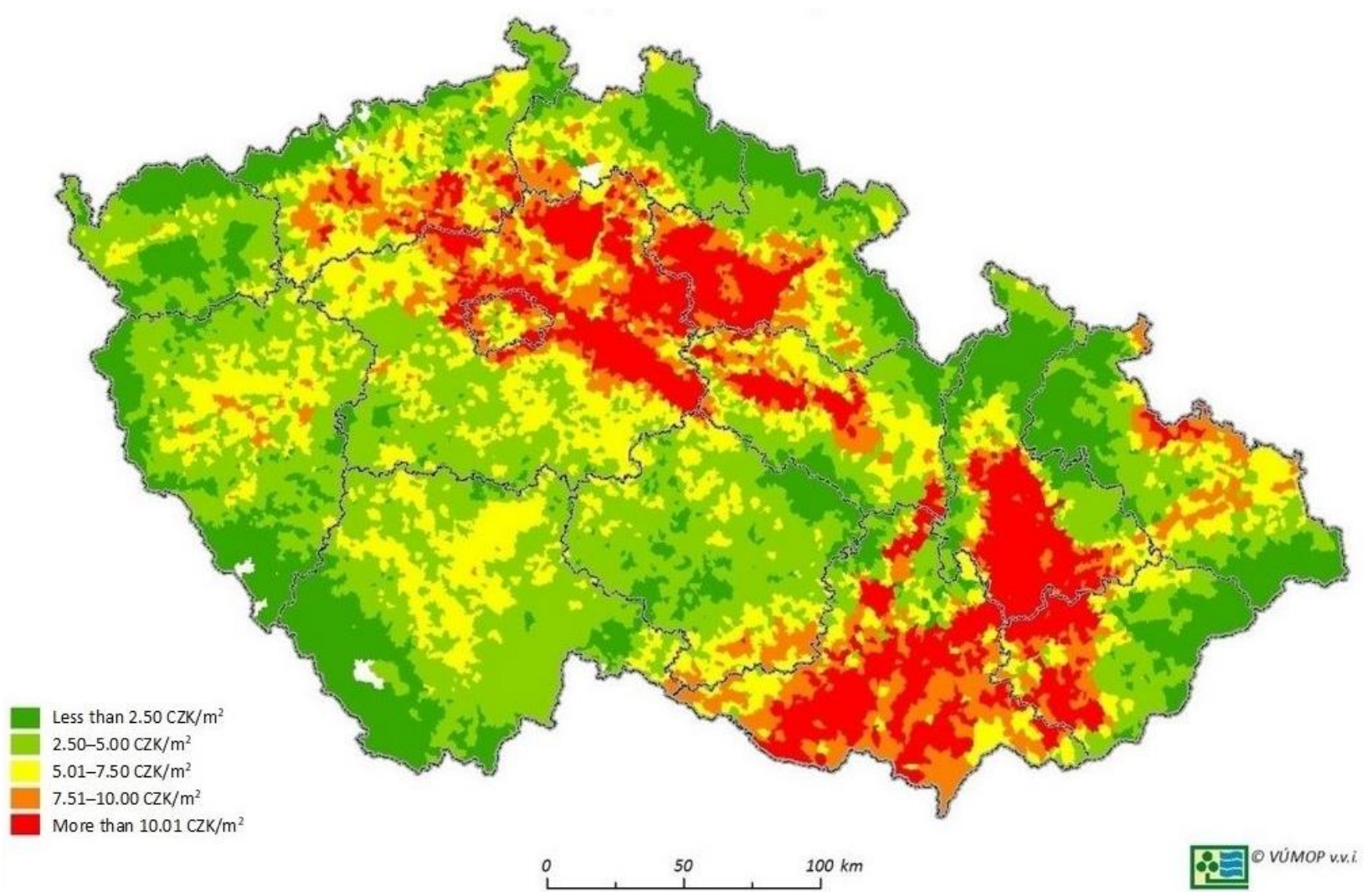

Figure 3. Average official price of agricultural land by cadastral territory. 
Due to the size of the article, only the ESEUs for the zeroth climate region are set forth in Table 3. When calculating the chain index between the individual 2002 and 1997 decrees, we can state that, out of the total number of codes, the price was reduced for 568 ESEU codes. In the case of the remaining codes, the price stagnated or increased. The price change methodology itself is not described in the decree. In this case, the evaluated period was described in more detail given the considerable volatility of individual ESEU code prices.

Table 3. Chain and basis index for ESEUs (1997, 2002, 2008, 2013, climate region 0).

\begin{tabular}{|c|c|c|c|c|c|c|c|c|c|}
\hline ESEU & Chain01/97 & Chain08/01 & Chain13/08 & Basis13/97 & ESEU & Chain01/97 & Chain08/01 & Chain13/08 & Basis13/97 \\
\hline 00100 & $100.6 \%$ & $116.8 \%$ & $114.7 \%$ & $134.8 \%$ & 03231 & $113.2 \%$ & $120.2 \%$ & $114.6 \%$ & $155.8 \%$ \\
\hline 00110 & $100.3 \%$ & $117.0 \%$ & $114.7 \%$ & $134.6 \%$ & 03234 & $60.4 \%$ & $126.8 \%$ & $114.6 \%$ & $87.8 \%$ \\
\hline 00112 & $101.7 \%$ & $117.2 \%$ & $114.7 \%$ & $136.7 \%$ & 03241 & $x$ & $124.9 \%$ & $114.6 \%$ & $x$ \\
\hline 00300 & $105.9 \%$ & $116.6 \%$ & $114.7 \%$ & $141.6 \%$ & 03244 & $x$ & $133.0 \%$ & $114.5 \%$ & $x$ \\
\hline 00401 & $110.5 \%$ & $118.8 \%$ & $114.7 \%$ & $150.6 \%$ & 03251 & $x$ & $122.5 \%$ & $114.7 \%$ & $x$ \\
\hline 00411 & $x$ & $119.4 \%$ & $114.8 \%$ & $x$ & 03254 & $53.9 \%$ & $129.5 \%$ & $114.6 \%$ & $80.0 \%$ \\
\hline 00501 & $99.1 \%$ & $118.0 \%$ & $114.8 \%$ & $134.2 \%$ & 03715 & $58.3 \%$ & $131.0 \%$ & $114.5 \%$ & $87.5 \%$ \\
\hline 00511 & $100.4 \%$ & $118.7 \%$ & $114.7 \%$ & $136.6 \%$ & 03716 & $65.6 \%$ & $134.7 \%$ & $114.7 \%$ & $101.3 \%$ \\
\hline 00600 & $102.7 \%$ & $117.2 \%$ & $114.7 \%$ & $138.1 \%$ & 03745 & $x$ & $136.7 \%$ & $114.6 \%$ & $x$ \\
\hline 00602 & $107.8 \%$ & $117.5 \%$ & $114.7 \%$ & $145.3 \%$ & 03746 & $x$ & $141.9 \%$ & $114.3 \%$ & $x$ \\
\hline 00610 & $109.7 \%$ & $117.5 \%$ & $114.7 \%$ & $147.7 \%$ & 03755 & $64.3 \%$ & $133.3 \%$ & $114.6 \%$ & $98.2 \%$ \\
\hline 00612 & $107.8 \%$ & $117.9 \%$ & $114.7 \%$ & $145.8 \%$ & 03756 & $66.9 \%$ & $138.6 \%$ & $114.8 \%$ & $106.5 \%$ \\
\hline 00640 & $x$ & $118.1 \%$ & $114.7 \%$ & $x$ & 03815 & $x$ & $129.4 \%$ & $114.8 \%$ & $x$ \\
\hline 00650 & $132.4 \%$ & $117.9 \%$ & $114.7 \%$ & $179.1 \%$ & 03816 & $x$ & $132.7 \%$ & $114.4 \%$ & $x$ \\
\hline 00700 & $130.9 \%$ & $117.0 \%$ & $114.7 \%$ & $175.8 \%$ & 03845 & $x$ & $134.7 \%$ & $114.4 \%$ & $x$ \\
\hline 00710 & $133.5 \%$ & $117.3 \%$ & $114.7 \%$ & $179.5 \%$ & 03846 & $x$ & $139.7 \%$ & $114.7 \%$ & $x$ \\
\hline 00740 & $x$ & $118.0 \%$ & $114.7 \%$ & $x$ & 03855 & $x$ & $131.9 \%$ & $115.0 \%$ & $x$ \\
\hline 00750 & $161.3 \%$ & $117.7 \%$ & $114.7 \%$ & $217.9 \%$ & 03856 & $x$ & $137.1 \%$ & $114.8 \%$ & $x$ \\
\hline 00800 & $97.4 \%$ & $117.1 \%$ & $114.7 \%$ & $130.8 \%$ & 03909 & $x$ & $141.1 \%$ & $114.6 \%$ & $x$ \\
\hline 00810 & $98.2 \%$ & $117.5 \%$ & $114.7 \%$ & $132.3 \%$ & 03919 & $x$ & $141.1 \%$ & $114.6 \%$ & $x$ \\
\hline 00840 & $100.3 \%$ & $118.4 \%$ & $114.7 \%$ & $136.2 \%$ & 03929 & $110.8 \%$ & $141.7 \%$ & $114.7 \%$ & $180.0 \%$ \\
\hline 00850 & $119.4 \%$ & $117.8 \%$ & $114.7 \%$ & $161.3 \%$ & 03939 & $112.3 \%$ & $141.1 \%$ & $114.6 \%$ & $181.5 \%$ \\
\hline 01811 & $139.3 \%$ & $118.3 \%$ & $114.6 \%$ & $188.8 \%$ & 03949 & $112.5 \%$ & $141.7 \%$ & $114.7 \%$ & $182.8 \%$ \\
\hline 01901 & $111.4 \%$ & $117.5 \%$ & $114.7 \%$ & $150.2 \%$ & 03959 & $x$ & $141.7 \%$ & $0.0 \%$ & $x$ \\
\hline 01904 & $x$ & $118.8 \%$ & $114.7 \%$ & $x$ & 03969 & $122.4 \%$ & $142.3 \%$ & $114.9 \%$ & $200.0 \%$ \\
\hline 01911 & $123.5 \%$ & $117.8 \%$ & $114.8 \%$ & $166.9 \%$ & 04067 & $93.5 \%$ & $141.7 \%$ & $114.7 \%$ & $151.9 \%$ \\
\hline 01914 & $112.0 \%$ & $119.4 \%$ & $114.6 \%$ & $153.3 \%$ & 04068 & $96.0 \%$ & $141.7 \%$ & $114.7 \%$ & $156.0 \%$ \\
\hline 01941 & $102.4 \%$ & $119.0 \%$ & $114.7 \%$ & $139.8 \%$ & 04077 & $91.3 \%$ & $141.1 \%$ & $114.6 \%$ & $147.5 \%$ \\
\hline 01944 & $x$ & $122.1 \%$ & $114.7 \%$ & $x$ & 04078 & $92.3 \%$ & $141.7 \%$ & $114.7 \%$ & $150.0 \%$ \\
\hline 01951 & $115.8 \%$ & $118.3 \%$ & $114.8 \%$ & $157.1 \%$ & 04089 & $98.6 \%$ & $142.3 \%$ & $114.9 \%$ & $161.1 \%$ \\
\hline 01954 & $94.8 \%$ & $120.5 \%$ & $114.7 \%$ & $131.1 \%$ & 04099 & $96.0 \%$ & $141.7 \%$ & $114.7 \%$ & $156.0 \%$ \\
\hline 02001 & $103.4 \%$ & $118.5 \%$ & $114.7 \%$ & $140.6 \%$ & 04167 & $93.5 \%$ & $141.7 \%$ & $114.7 \%$ & $151.9 \%$ \\
\hline 02004 & $119.0 \%$ & $119.8 \%$ & $114.7 \%$ & $163.6 \%$ & 04168 & $96.0 \%$ & $141.7 \%$ & $114.7 \%$ & $156.0 \%$ \\
\hline 02011 & $113.0 \%$ & $118.7 \%$ & $114.7 \%$ & $153.9 \%$ & 04177 & $92.4 \%$ & $141.1 \%$ & $114.6 \%$ & $149.4 \%$ \\
\hline
\end{tabular}


Table 3. Cont.

\begin{tabular}{|c|c|c|c|c|c|c|c|c|c|}
\hline ESEU & Chain01/97 & Chain08/01 & Chain13/08 & Basis13/97 & ESEU & Chain01/97 & Chain08/01 & Chain13/08 & Basis13/97 \\
\hline 02014 & $100.0 \%$ & $120.8 \%$ & $114.8 \%$ & $138.6 \%$ & 04178 & $93.5 \%$ & $141.7 \%$ & $114.7 \%$ & $151.9 \%$ \\
\hline 02041 & $103.4 \%$ & $120.2 \%$ & $114.7 \%$ & $142.4 \%$ & 04189 & $100.0 \%$ & $142.3 \%$ & $114.9 \%$ & $163.4 \%$ \\
\hline 02044 & $72.4 \%$ & $125.1 \%$ & $114.9 \%$ & $104.0 \%$ & 04199 & $96.0 \%$ & $141.7 \%$ & $114.7 \%$ & $156.0 \%$ \\
\hline 02051 & $109.6 \%$ & $119.5 \%$ & $114.7 \%$ & $150.1 \%$ & 05500 & $116.8 \%$ & $118.3 \%$ & $114.8 \%$ & $158.5 \%$ \\
\hline 02054 & $89.3 \%$ & $122.8 \%$ & $114.8 \%$ & $125.9 \%$ & 05600 & $92.0 \%$ & $117.0 \%$ & $114.7 \%$ & $123.5 \%$ \\
\hline 02110 & $118.0 \%$ & $120.1 \%$ & $114.6 \%$ & $162.5 \%$ & 05700 & $98.7 \%$ & $117.1 \%$ & $114.7 \%$ & $132.5 \%$ \\
\hline 02112 & $120.9 \%$ & $120.8 \%$ & $114.8 \%$ & $167.7 \%$ & 05800 & $80.5 \%$ & $117.3 \%$ & $114.8 \%$ & $108.4 \%$ \\
\hline 02113 & $116.0 \%$ & $121.6 \%$ & $114.8 \%$ & $162.0 \%$ & 05900 & $88.1 \%$ & $117.9 \%$ & $114.7 \%$ & $119.2 \%$ \\
\hline 02142 & $85.1 \%$ & $123.6 \%$ & $114.8 \%$ & $120.8 \%$ & 06000 & $99.8 \%$ & $116.7 \%$ & $114.7 \%$ & $133.6 \%$ \\
\hline 02143 & $x$ & $125.8 \%$ & $114.5 \%$ & $x$ & 06100 & $103.6 \%$ & $116.9 \%$ & $114.7 \%$ & $138.9 \%$ \\
\hline 02152 & $104.1 \%$ & $122.0 \%$ & $114.8 \%$ & $145.8 \%$ & 06200 & $87.4 \%$ & $117.1 \%$ & $114.7 \%$ & $117.4 \%$ \\
\hline 02153 & $101.2 \%$ & $123.2 \%$ & $114.9 \%$ & $143.2 \%$ & 06300 & $64.2 \%$ & $120.7 \%$ & $114.7 \%$ & $89.0 \%$ \\
\hline 02210 & $128.2 \%$ & $119.3 \%$ & $114.8 \%$ & $175.5 \%$ & 06401 & $69.1 \%$ & $120.0 \%$ & $114.8 \%$ & $95.1 \%$ \\
\hline 02212 & $123.0 \%$ & $119.9 \%$ & $114.8 \%$ & $169.2 \%$ & 06411 & $x$ & $120.4 \%$ & $114.7 \%$ & $x$ \\
\hline 02213 & $118.1 \%$ & $120.4 \%$ & $114.7 \%$ & $163.2 \%$ & 06501 & $85.4 \%$ & $125.4 \%$ & $114.9 \%$ & $123.0 \%$ \\
\hline 02242 & $89.9 \%$ & $121.8 \%$ & $114.8 \%$ & $125.8 \%$ & 06511 & $x$ & $125.8 \%$ & $114.5 \%$ & $x$ \\
\hline 02243 & $x$ & $122.3 \%$ & $114.9 \%$ & $x$ & 06601 & $x$ & $135.8 \%$ & $114.7 \%$ & $x$ \\
\hline 02252 & $104.0 \%$ & $120.8 \%$ & $114.8 \%$ & $144.2 \%$ & 06701 & $102.2 \%$ & $135.8 \%$ & $114.7 \%$ & $159.1 \%$ \\
\hline 02253 & $102.3 \%$ & $121.5 \%$ & $114.8 \%$ & $142.8 \%$ & 06811 & $x$ & $136.2 \%$ & $114.8 \%$ & $x$ \\
\hline 02310 & $114.5 \%$ & $119.6 \%$ & $114.7 \%$ & $157.1 \%$ & 06841 & $x$ & $137.1 \%$ & $114.8 \%$ & $x$ \\
\hline 02312 & $117.8 \%$ & $120.3 \%$ & $114.7 \%$ & $162.6 \%$ & 06901 & $124.7 \%$ & $131.9 \%$ & $115.0 \%$ & $189.2 \%$ \\
\hline 02313 & $118.4 \%$ & $120.6 \%$ & $114.7 \%$ & $163.8 \%$ & 07001 & $159.7 \%$ & $120.5 \%$ & $114.7 \%$ & $220.8 \%$ \\
\hline 02411 & $104.5 \%$ & $118.7 \%$ & $114.7 \%$ & $142.2 \%$ & 07101 & $x$ & $121.6 \%$ & $114.7 \%$ & $x$ \\
\hline 02414 & $75.7 \%$ & $121.8 \%$ & $114.8 \%$ & $105.9 \%$ & 07201 & $125.3 \%$ & $131.1 \%$ & $114.7 \%$ & $188.4 \%$ \\
\hline 02441 & $79.3 \%$ & $121.0 \%$ & $114.7 \%$ & $110.1 \%$ & 07311 & $x$ & $139.5 \%$ & $115.0 \%$ & $x$ \\
\hline 02444 & $x$ & $127.6 \%$ & $114.6 \%$ & $x$ & 07313 & $x$ & $140.0 \%$ & $114.3 \%$ & $x$ \\
\hline 02451 & $93.3 \%$ & $119.8 \%$ & $114.8 \%$ & $128.2 \%$ & 07341 & $x$ & $139.2 \%$ & $114.5 \%$ & $x$ \\
\hline 02454 & $x$ & $124.7 \%$ & $114.6 \%$ & $\mathrm{x}$ & 07343 & $x$ & $139.7 \%$ & $114.7 \%$ & $x$ \\
\hline 02901 & $103.3 \%$ & $118.4 \%$ & $114.7 \%$ & $140.3 \%$ & 07411 & $x$ & $139.5 \%$ & $115.0 \%$ & $x$ \\
\hline 02904 & $82.8 \%$ & $120.5 \%$ & $114.7 \%$ & $114.5 \%$ & 07413 & $x$ & $140.0 \%$ & $114.3 \%$ & $x$ \\
\hline 02911 & $98.9 \%$ & $119.0 \%$ & $114.7 \%$ & $134.9 \%$ & 07441 & $x$ & $139.2 \%$ & $114.5 \%$ & $x$ \\
\hline 02914 & $70.8 \%$ & $122.0 \%$ & $114.6 \%$ & $99.0 \%$ & 07443 & $x$ & $139.7 \%$ & $114.7 \%$ & $x$ \\
\hline 02941 & $69.8 \%$ & $121.2 \%$ & $114.6 \%$ & $96.9 \%$ & 07541 & $x$ & $137.1 \%$ & $114.8 \%$ & $x$ \\
\hline 02944 & $x$ & $128.2 \%$ & $114.7 \%$ & $x$ & 07543 & $x$ & $137.5 \%$ & $114.9 \%$ & $x$ \\
\hline 02951 & $x$ & $120.2 \%$ & $114.6 \%$ & $x$ & 07641 & $x$ & $137.1 \%$ & $114.8 \%$ & $x$ \\
\hline 02954 & $50.4 \%$ & $126.0 \%$ & $114.9 \%$ & $73.0 \%$ & 07643 & $x$ & $137.5 \%$ & $114.9 \%$ & $x$ \\
\hline 03201 & $121.3 \%$ & $119.3 \%$ & $114.7 \%$ & $166.1 \%$ & 07769 & $116.4 \%$ & $142.3 \%$ & $114.9 \%$ & $190.2 \%$ \\
\hline 03204 & $69.6 \%$ & $123.9 \%$ & $114.8 \%$ & $99.0 \%$ & 07789 & $x$ & $142.9 \%$ & $115.0 \%$ & $x$ \\
\hline 03221 & $97.0 \%$ & $121.0 \%$ & $114.6 \%$ & $134.6 \%$ & 07869 & $x$ & $142.3 \%$ & $114.9 \%$ & $x$ \\
\hline 03224 & $59.3 \%$ & $127.6 \%$ & $114.6 \%$ & $86.7 \%$ & 07889 & $118.6 \%$ & $142.9 \%$ & $115.0 \%$ & $194.9 \%$ \\
\hline
\end{tabular}


If we look at the results in more detail, according to individual climate regions, we can say that, in the case of climate region 0 , there was a reduction in price for 48 out of 148 ESEU codes. The most significant decrease was in code 02954 (a decrease from CZK 3.6 to CZK 1.81); in this case, the price decreased by $50 \%$. In contrast, the greatest increase was recorded for codes 00750 (an increase from CZK 4.76 to CZK 7.68) and 07001 (an increase from CZK 2.26 to CZK 3.61), being $60 \%$. The average price increase in this climate region was $0.8 \%$. In climate region 1, 221 ESEU codes were analysed, whereby the price decreased in 82 of them, and a price increase was recorded in the others. The most significant decrease occurred in code 12844 (a price decrease from CZK 3 to CZK 1.91), which represented a $36 \%$ decrease. In contrast, the most significant price increase occurred in code 13001 (a price increase from CZK 4.03 to CZK 6.21), which represented a 54\% increase. The average price increase in this climate region was $4.6 \%$. In climate region 2, 206 codes were analysed. Out of the aforementioned number, the price decreased in 49 , while, for the remaining codes, the price stayed the same or increased. The most significant decrease occurred in the case of code 23755, being 37\% (a decrease from CZK 1.89 to CZK 1.19). In contrast, the most significant increase was in code 23001 , where the price increased by $52 \%$ (an increase from CZK 4.84 to CZK 7.38). The average price increase in this climate region was $9.5 \%$. In climate region 3, 250 codes were analysed. Out of the given number, the price decreased in 45 ESEUs, while the remaining ones recorded a price increase. The most significant decrease occurred in the case of code 33816, being $42 \%$ (a decrease from CZK 2.38 to CZK 1.39). In contrast, the greatest increase was in code 36501, where the price increased by $73.5 \%$ (an increase from CZK 2.15 to CZK 3.73). The average price increase in this climate region was $12.9 \%$. In climate region 4,246 codes were analysed. Out of the given number, the price decreased in 83 ESEUs, while the remaining ones recorded a price increase. The most significant decrease occurred in the case of code 43855 , being $40 \%$ (a decrease from CZK 1.72 to CZK 1.03). In contrast, the greatest increase was in code 42313 , where the price increased by $75 \%$ (an increase from CZK 1.75 to CZK 3.07). The average price increase in this climate region was $8.5 \%$. In climate region 5, 260 codes were analysed. Out of the given number, the price decreased in 64 ESEUs, while the remaining ones recorded a price increase. The most significant decrease occurred in the case of code 53344 , being $34 \%$ (a decrease from CZK 2.87 to CZK 1.89). In contrast, the greatest increase was in code 53949 , where the price increased by $216 \%$ (an increase from CZK 0.68 to CZK 2.15). The average price increase in this climate region was $14.7 \%$. In climate region 6 , 242 codes were analysed. Out of the given number, the price decreased in 100 ESEUs, while the remaining ones recorded a price increase. The most significant decrease occurred in the case of code 63816 , being $54 \%$ (a decrease from CZK 1.72 to CZK 0.79). In contrast, the greatest increase was in code 61602 , where the price increased by $50 \%$ (an increase from CZK 3.59 to CZK 5.38). The average price increase in this climate region was 3.7\%. In climate region 7, 246 codes were analysed. Out of the given number, the price decreased in 100 ESEUs, while the remaining ones recorded a price increase. The most significant decrease occurred in the case of code 73314, being 35\% (a decrease from CZK 3.41 to CZK 2.20). In contrast, the greatest increase was in code 72313 , where the price increased by $83.5 \%$ (an increase from CZK 1.39 to CZK 2.55). The average price increase in this climate region was $8.5 \%$. In climate region 8,119 codes were analysed. Out of the given number, the price decreased in 41 ESEUs, while the remaining ones recorded a price increase. The most significant decrease occurred in the case of code 83524, being $43 \%$ (a decrease from CZK 2.95 to CZK 1.69). In contrast, the greatest increase was in code 86501, where the price increased by $74 \%$ (an increase from CZK 1.32 to CZK 2.30). The average price increase in this climate region was $3.5 \%$. In climate region 9, 74 codes were analysed. Out of the given number, the price decreased in only four ESEUs, while the remaining ones recorded a price increase. The most significant decrease occurred in the case of code 95051, being 5\% (a decrease from CZK 1.01 to CZK 0.96). In contrast, the greatest increase was in code 93756, where the price increased by $52 \%$ (an increase from CZK 0.50 to CZK 0.76). The average price increase in this climate region was $14.8 \%$. 
In terms of the movement of individual ESEU code prices, the period between 1997 and 2002 was considerably volatile, with a significant revaluation both upwards and downwards.

Other changes in prices between 2002 and 2008 were practically only upwards. The only exceptions were two ESEU codes out of the total number of 2199 codes applicable for this period; specifically, they were 53949 and 53939, where the prices decreased by $51 \%$ and $48 \%$, respectively.

Between 2008 and 2013, the prices changed the same way in all the climate regions, with prices rising by an average of $14.7 \%$. The only exception was code 71502 , where the price stayed the same as in 2008, at a level of CZK 6.23. In the case of the other codes (2172 codes were applicable for 2013), the price increased within a range of 14.3-15.1\%. The results showed a uniform shift in prices. In this case, it was already mentioned that inflation was reflected in the price growth.

When assessing the basic index of ESEU code prices, in the analysed period of 1997 to 2013 (the still-applicable price decree), the prices decreased for 65 codes. The decreases were not significant and fluctuated between $1 \%$ and $27 \%$. Four codes had the same price as in 1997, while the remaining ones saw a price increase of between $1 \%$ and $331 \%$. The most significant increase occurred in code 56511 , with an increase from 1.55 to $5.13 \mathrm{CZK} / \mathrm{m}^{2}$.

\subsection{Results of a Hedonic Approach to Shadow Pricing of Input Parameters}

Furthermore, econometric models were created for individual valuation decrees. The methodology by which the variables were created and included is set forth in the work methodology (see Table 1). For clarity, only the parameters of individual input variables are given (the complete models for individual years are then given in the Appendix A to this article-Appendices A.1-A.4). Most of the estimated parameters were highly significant, even at a significance level of $1 \%$. The only exceptions were a few main soil unit parameters. Together with other model characteristics, the indicator $\mathrm{R}^{2}$, as a gauge of concord, indicated good statistical properties. $\mathrm{R}^{2}$ pointed out the fact that $95 \%$ of ESEU prices were explained by the used variables. The explanatory ability of the hedonic model, with a high parametric significance for most of the used variables, was an important factor determining the robustness of the model as a repricing tool. The logical consistency of the input parameters is discussed further in the text. The values of the individual variables' parameters represent shadow prices, which will then be used in the case of the valuation of new or not-yet-valued codes. In the applicable price Decree no. 441/2013 Coll., there are 295 codes that must be valued, primarily for tax purposes.

In individual price decrees that involved price adjustments (1997, 2002, 2008 and 2013), there was also a change in the coefficient for the individual shadow prices of climate regions 1-9. When comparing shadow prices (Table 4), it was evident that the climate region that fared best was K3 (warm, slightly humid), which reflected a generally applicable fact in terms of the climate region's basic characteristics. This assumption was fulfilled in individual models and price decrees, where climate region 3 fared best in all of them. In terms of the development of shadow prices over time, it was evident that the development was dichotomous, but the basic trend was the same in all the climate regions. If the coefficient for the given climate region was positive, then it increased over time; i.e., the shadow price dynamic grew, whereby the most significant increase was in the value of climate region 3. Similarly, if the region's coefficient was negative, then it also increased over time, in which case, however, we can state that its shadow price decreased over time. A curiosity was climate region 5, which still showed positive coefficient values in 1997, but then we can see its decline and gradual decrease into negative values. Overall, it can also be stated that the partial changes between the observed periods had decreasing values, i.e., at the beginning of the observed period, there were more pronounced changes than at its end. Another reason for setting shadow prices is the fact that, due to climate change, the climate regions' tabular characteristics do not correspond to the actual values (e.g., average temperature), which can lead to an inappropriately set price [36]. The original methodology for the distribution of climatic regions (see Figure 2) currently allows us to 
unambiguously classify only $17 \%$ of the entire territory of the Czech Republic (and 18\% of Czech agricultural land). A significant part of the territory does not fit into the individual climatic regions according to the table characteristics [37].

Table 4. Shadow prices for climate regions.

\begin{tabular}{ccccc}
\hline Variables & Coefficient 1997 & Coefficient 2002 & Coefficient 2008 & Coefficient 2013 \\
\hline Const & 8397 & 11,388 & 13,319 & 15,275 \\
\hline K1 & -0.355 & -0.478 & -0.557 & -0.644 \\
\hline K2 & 0.092 & 0.266 & 0.294 & 0.335 \\
\hline K3 & 0.554 & 1.105 & 1.258 & 1.436 \\
\hline K4 & -0.229 & -0.717 & -0.831 & -0.954 \\
\hline K5 & 0.052 & -0.167 & -0.208 & -0.242 \\
\hline K6 & -0.126 & -0.451 & -0.527 & -0.613 \\
\hline K7 & -0.412 & -1.196 & -1.381 & -1.594 \\
\hline K8 & -0.668 & -1.529 & -1.755 & -2.020 \\
\hline K9 & -0.502 & -1.340 & -1.533 & -1.779 \\
\hline
\end{tabular}

Source: own calculations.

The effect of climate change on the total production of various crops was examined by several studies, e.g., [38-41]. As the calculation for determining production potential, and thereby also the ESEU prices, is based on Formula (1), in the future, it will be necessary to incorporate the effect of climate change on the yields of individual crops when calculating the parameterised production prices.

Similarly to the variables for the climate regions, it was possible to evaluate the shadow prices in the case of a combined code for slope and directional orientation. The results showed that, in this case, the shadow prices in individual periods changed depending on the change in the ESEU price given by the decree. Nevertheless, a closer look at the individual values showed that a more detailed classification of exposure within a combined code had a valid premise. In the case of the price decree applicable for 2013, we found that, for climate regions $0-5$, the southern side had a higher coefficient value, which, under the conditions of ceteris paribus, also caused lower prices (however, this assumption also applied for older price decrees from 1997, 2002 and 2008). Table 5 shows the outputs of the shadow price coefficients for the combined soil properties of the slope and exposure. Thanks to the negative values, it was evident from the overview that any deviation from the basic slope and exposure values led to a decrease in shadow prices, i.e., an increase in slope and directional exposure, compared with flat, unexposed land, which always caused a price decrease. The aforementioned applied regardless of the degree of slope, and even regardless of exposure orientation, which can be considered a relatively fundamental output, which is probably connected with the problematic absorption of water in sloping land and thereby the overall water balance deficit.

If we take land exposure into account, then the climate region in which the land was located also plays a relatively fundamental role. In climate regions 6-9, northern exposure had a higher coefficient value than the others (southern, western, eastern), which led to lower land prices. In this case, this conclusion was completely logical because these were plots of land that were exposed to less sunlight, and therefore, also had worse conditions for growing crops. In contrast, considering climate regions 0-5 (warm climate regions) into account, then southern exposure had a higher coefficient value (compared with northern, eastern and southern exposure), which again meant lower prices. This conclusion was again logically correct due to drier areas and considerable evapotranspiration. For example, [42] pointed out the interaction of the effects of temperature, solar radiation and surface temperature on evapotranspiration. 
Table 5. Shadow prices for combined codes indicating land slope and exposition.

\begin{tabular}{ccccc}
\hline Variables & Coefficient 1997 & Coefficient 2002 & Coefficient 2008 & Coefficient 2013 \\
\hline SDR1 & -0.794 & -0.810 & -0.932 & -1.069 \\
\hline SDR2a & -1.165 & -1.477 & -1.676 & -1.928 \\
\hline SDR2b & -0.953 & -0.796 & -0.908 & -1.038 \\
\hline SDR3a & -1.149 & -0.940 & -1.073 & -1.229 \\
\hline SDR3b & -0.981 & -1.282 & -1.518 & -1.748 \\
\hline SDR4a & -1.638 & -1.725 & -1.984 & -2.279 \\
\hline SDR4b & -1.496 & -1.330 & -1.536 & -1.757 \\
\hline SDR5a & -1.762 & -1.458 & -1.682 & -1.923 \\
\hline SDR5b & -1.439 & -1.564 & -1.799 & -2.068 \\
\hline SDR6a & -1.588 & -1.295 & -1.383 & -1.598 \\
\hline SDR6b & -1.131 & -0.290 & -0.242 & -0.271 \\
\hline SDR7a & -1.186 & -0.351 & -0.310 & -0.352 \\
\hline SDR7b & -1.566 & -1.199 & -1.270 & -1.463 \\
\hline SDR8a & -1.638 & -1.193 & -1.262 & -1.453 \\
\hline SDR8b & -1.219 & -0.355 & -0.314 & -0.357 \\
\hline SDR9a & -1.235 & -0.353 & -0.312 & -0.354 \\
\hline SDR9b & -1.627 & -1.192 & -1.263 & -1.455 \\
\hline Source: own calculations & & & & \\
\hline
\end{tabular}

Source: own calculations.

Soil erosion is a major challenge for agricultural regions. Terrain directly influences erosion through the slope and flow convergence. Arable land washouts represent economic damage that can be reflected in lower hectare yields [43].

Another important aspect for the future is to understand the relationship between crop yields and water requirements at a local scale in order to choose an appropriate adaptation strategy or to select appropriate crop rotations [44].

In hilly landscapes, the slope of the land plays an important role. In China, for example, agricultural land is created and can thus support the sustainable development of cultivated land resources in hilly areas. However, they should not be created on hills with a slope exceeding $25^{\circ}$. Depending on the slope of the terrain, four types of utilities (strip plots, flat terraces, sloping terraces and gentle slopes) can be considered for construction in hilly areas. These measures can greatly improve the fragmentation of cultivated land and effectively promote the mechanisation, large-scale production and industrialisation of agriculture [45].

In terms of development over time, the situation is very complicated, as the subcodes were relatively different in their development. Nevertheless, in general, we can probably state that the price decrease dynamic was roughly stable; in most codes, the price decreased by 1 or 2 units over the observed years. The exceptions were codes SDR6b,7a and SDR8b,9a. Here, the price decrease dynamic declined over time, especially in relation to 1997.

The following Table 6 contains the outputs of the estimated shadow price coefficients, which took into account the combined code that included the soil profile depth and skeletality. From the obtained results, it was quite clear that the price value decreased significantly towards worsening soil conditions, i.e., it was clearly shown that decreasing soil profile depth and its structure (in terms of skeletality) had a very intensive effect on reducing the soil value. Viewed in more detail, the aforementioned could be divided into two levels, where in codes SDRH1-4, the prices decreased, but the intensity was at a level of decrease of approximately 1-3 units ceteris paribus. Codes SDRH5-9 showed a decrease that was several times greater, which could probably be justified by both a soil profile depth that was too low for conventional production use and significantly deteriorating soil skeletality, which then prevented even alternative possibilities of use of the given soil type. In terms 
of the development of shadow prices over time, Table 6 shows a decreasing value over time due to the given code, whereby the change dynamic had a predominantly subdued character. A previous study [46] pointed out the effect of fertilisation depth in relation to yields and $\mathrm{N}_{2} \mathrm{O}$ emissions in corn, whereby the recommended fertilisation depth is $25 \mathrm{~cm}$. The soil profile depth is also important in relation to wind and water erosion. Sloping land with inappropriately selected crops may lose some of its production potential in the future due to the washing off of the fertile topsoil. According to a study by [47], crop yields did not decrease significantly with a soil profile depth of above $25 \mathrm{~cm}$. Another important result of the study came from the examination of the effect of erosion on production. If more than $20 \mathrm{~cm}$ of the topsoil is eroded, production decreases without the possibility of a return to pre-erosion production. Other studies considered the effect of rock fragment size on the protection of soil or water at various precipitation intensities. The results show that the size of the fragments in the soil affects production or erosion; for more details, see, for example, [48-50]. The combination of higher skeletality and higher land slope could lead to higher erosion activity, which was also negatively reflected in lower production capacity. This relationship was also evidenced by the higher negative coefficients and, by extension, shadow prices set forth in the following Table 6. Erosion leads to reduced topsoil thickness, and thereby, the soil profile depth. This relationship must again be reflected in the official prices within the scope of the ESEU because, in general, soil under this characteristic may transition to another level (see Table 1's detailed specifications).

Table 6. Shadow prices for combined codes indicating soil profile depth and skeletality.

\begin{tabular}{ccccc}
\hline Variables & Coefficient 1997 & Coefficient 2002 & Coefficient 2008 & Coefficient 2013 \\
\hline SDRH1 & -0.950 & -0.726 & -0.829 & -0.956 \\
\hline SDRH2 & -0.649 & -1.032 & -1.188 & -1.367 \\
\hline SDRH3 & -1.021 & -1.441 & -1.659 & -1.905 \\
\hline SDRH4 & -2.151 & -2.489 & -2.863 & -3.290 \\
\hline SDRH5 & -5.594 & -8.568 & -9.870 & -11.313 \\
\hline SDRH6 & -5.867 & -8.788 & -10.124 & -11.605 \\
\hline SDRH7 & -6.242 & -9.368 & -10.899 & -12.489 \\
\hline SDRH8 & -6.265 & -9.379 & -10.911 & -12.501 \\
\hline SDRH9 & -6.244 & -9.394 & -10.929 & -12.522 \\
\hline Source: own calculations. & & & &
\end{tabular}

Source: own calculations.

Given the model's very good capabilities, the aforementioned shadow prices (an overview of the individual models' coefficients is available in Appendices A.1-A.4) can be used for the valuation of new codes. Based on the given ESEU code specification (a five-digit number indicating the basic soil characteristics), valuation can be accelerated without the need to calculate GARE and determine production potential.

\section{Conclusions}

The main objective of this study was to determine the shadow prices of the input parameters affecting the price of ESEUs using an econometric model. Given the dual system of farmland prices, this study was innovative in its approach as it focused on the factors affecting the official price of land specifically through ESEU. The main contribution of this study was the possibility of applying shadow prices to newly proposed or not-yetpriced ESEU codes. This approach provides several key benefits for governments. The first advantage is the considerable speeding up of the whole process of ESEU pricing. The second advantage is the full application of the model, as it is based on soil survey data in the conditions of the Czech Republic. 
The indicated approach is, of course, limited by certain limitations, which resulted mainly from the methodological apparatus in the form of the applied hedonic model and, at the same time, the corresponding structure of the cross-sectional data, which did not allow for classical time series analysis. The basic factor that limits the use of the results in practice is the specification of the model and the achievement of the required properties of the estimated model. However, the model contains all the determinants that generate the ESEU code; therefore, its specification is complete and thus there is no risk of not including the relevant variables. At the same time, the outputs of the model were sufficiently verified in terms of the econometric and statistical properties of the estimate. Therefore, it can be stated that the achieved output is fully applicable for the basic goal, i.e., the valuation of new land blocks. For further research and use, the model can be relatively easily redefined with new units under consideration for a future climate change system.

The results showed that the main influence on the price of an ESEU was the depth of the soil profile, skeletonisation, slope and exposure. From the above, it could be concluded that with a lower soil profile and higher skeletonisation the price of an ESEU decreased. Similarly, with a higher slope, the price of an ESEU decreased again. An interesting result was then the effect of exposure on the price of ESEU. For climatic regions 0-5, the southern orientation of the plot was perceived more negatively in terms of coefficients than other exposure options. Conversely, for climate regions 6-9, the northern exposure was perceived as such. This assumption is generally perceived but can now be considered confirmed by the model results. In the case of the first research question, it can be concluded that the average price increased by more than $20 \%$ in the evaluated period. During the analysed period, there was also a gradual revaluation and more detailed mapping of ESEUs under the conditions in the Czech Republic. This fact led to the gradual expansion of the ESEU code database. The main reasons for the revaluation include taking into account the degradation changes in the soil, changes in soil hydromorphism and the need to supplement and refine the national database. Due to the aforementioned reasons, the number of codes is gradually increasing. For the second research question, it can therefore be stated that, in the evaluated period, the number of ESEU codes increased by 19.5\%. However, this increase did not include other, not-yet-valued codes, which are not listed in the decree (there are 295 more codes). If these are included, then the number of ESEU codes increases by more than 35\%. In addition to the advantages of this study, it is also necessary to mention any shortcomings. The shortcomings of this study lay in the application of only the production potential of the soil without considering other non-production functions of the soil (water infiltration, water filtration, water retention and storage, nutrient storage, buffering capacity, etc.). Future research may, therefore, consist of possibly extending the factors influencing the price of ESEUs to include these neglected factors. Furthermore, future research may consist of a more detailed characterisation of the main soil units with regard to retention capacity, which will also be important for the production potential of agricultural soils under the conditions of the Czech Republic and, more generally, in the world in view of climate change.

Author Contributions: J.S.: methodology, conceptualisation, partial calculations, analyses and evaluations and writing — review and editing. M.M.: partial calculations, control of results, writing — review and editing and evaluations. All authors have read and agreed to the published version of the manuscript.

Funding: The APC was funded by the Faculty of Economics and Management (FEM), Czech University of Life Sciences Prague.

Institutional Review Board Statement: Not applicable for study.

Informed Consent Statement: Not applicable for study.

Data Availability Statement: The datasets analysed during the current study are available in Decree No. 151/1997 Sb. of 31 December 1997 for execution of the Act on Property Valuation (Valuation Decree), Czech Republic (in Czech), available at https:/ / www.zakonyprolidi.cz/cs/1997-151 (accessed on 23 October 2021); Decree No. 540/2002 Sb. of 31 December 2002 for execution of the Act on Property Valuation (Valuation Decree), Czech Republic (in Czech), Annex No. 19, available 
at https:/ / www.zakonyprolidi.cz/cs / 2002-540 (accessed on 23 October 2021); Decree No. 3/2008 Sb. of 1 February 2008 for execution of the Act on Property Valuation (Valuation Decree), Czech Republic (in Czech), Annex No. 22, available at https://www.zakonyprolidi.cz/cs/2008-3 (accessed on 23 October 2021); Decree No. 441/2013 Sb. of 17 December 2013 for execution of the Act on Property Valuation (Valuation Decree), Czech Republic (in Czech), Annex No. 4, available at https:/ / www.zakonyprolidi.cz/cs/2013-441 (accessed on 23 October 2021).

Acknowledgments: This paper was created within the framework of the project NAZV QK1920280Innovation of bonitation system of agricultural lands (ESEU) for the needs of state administration. Supported by the Ministry of Agriculture of the Czech Republic. Program ZEMĚ.

Conflicts of Interest: The authors declare no conflict of interest. The funders had no role in the design of the study; in the collection, analyses, or interpretation of data; in the writing of the manuscript; or in the decision to publish the results.

\section{Appendix A}

Appendix A.1. Econometric Model for Variables Based on Decree No. 151/1997 Coll

\begin{tabular}{|c|c|c|c|c|c|c|c|c|c|}
\hline Variables & Coefficient & Std. Error & t-Ratio & $p$-Value & Variables & Coefficient & Std. Error & t-Ratio & $p$-Value \\
\hline Const & 8.397 & 0.698 & 12.02 & $3.07 \times 10^{-32 * * *}$ & D_21 & -4.343 & 0.701 & -6.20 & $6.83 \times 10^{-10 * * *}$ \\
\hline K1 & -0.355 & 0.087 & -4.10 & $4.38 \times 10^{-5 * * *}$ & D_22 & -3.767 & 0.701 & -5.38 & $8.49 \times 10^{-8 * * *}$ \\
\hline K2 & 0.092 & 0.082 & 1.12 & 0.2617 & D_23 & -4.426 & 0.700 & -6.33 & $3.10 \times 10^{-10 * * *}$ \\
\hline $\mathrm{K} 3$ & 0.554 & 0.082 & 6.76 & $1.83 \times 10^{-11 * * *}$ & D_24 & -2.288 & 0.725 & -3.16 & $0.0016^{* * *}$ \\
\hline K4 & -0.229 & 0.072 & -3.17 & $0.0015^{* * *}$ & D_25 & -1.651 & 0.714 & -2.31 & $0.0209 * *$ \\
\hline K5 & 0.052 & 0.069 & 0.75 & 0.451 & D_26 & -2.131 & 0.712 & -2.99 & $0.0028^{* * *}$ \\
\hline K6 & -0.126 & 0.092 & -1.36 & 0.1738 & D_27 & -3.148 & 0.714 & -4.41 & $1.10 \times 10^{-5 * * *}$ \\
\hline K7 & -0.412 & 0.086 & -4.81 & $1.60 \times 10^{-6 * * *}$ & D_28 & -2.163 & 0.738 & -2.93 & $0.0034^{* * *}$ \\
\hline K8 & -0.668 & 0.097 & -6.88 & $7.73 \times 10^{-12 * * *}$ & D_29 & -2.049 & 0.713 & -2.87 & $0.0041^{* * *}$ \\
\hline K9 & -0.502 & 0.100 & -5.02 & $5.68 \times 10^{-7 * * *}$ & D_30 & -2.770 & 0.714 & -3.88 & $0.0001^{* * *}$ \\
\hline SDR1 & -0.794 & 0.056 & -14.07 & $5.53 \times 10^{-43 * * *}$ & D_31 & -3.647 & 0.718 & -5.08 & $4.17 \times 10^{-7 * * *}$ \\
\hline SDR2a & -1.165 & 0.194 & -6.01 & $2.19 \times 10^{-9 * * *}$ & D_32 & -3.070 & 0.716 & -4.29 & $1.88 \times 10^{-5 * * *}$ \\
\hline SDR2b & -0.953 & 0.179 & -5.33 & $1.08 \times 10^{-7 * * *}$ & D_33 & -1.900 & 0.720 & -2.64 & $0.0084^{* * *}$ \\
\hline SDR3a & -1.149 & 0.183 & -6.27 & $4.36 \times 10^{-10 * * *}$ & D_34 & -2.360 & 0.766 & -3.08 & $0.0021^{* * *}$ \\
\hline SDR3b & -0.981 & 0.168 & -5.84 & $5.97 \times 10^{-9 * * *}$ & D_35 & -2.171 & 0.781 & -2.78 & $0.0055^{* * *}$ \\
\hline SDR4a & -1.638 & 0.068 & -23.94 & $5.48 \times 10^{-112 * * *}$ & D_36 & -3.823 & 0.735 & -5.21 & $2.13 \times 10^{-7 * * *}$ \\
\hline SDR4b & -1.496 & 0.082 & -18.34 & $9.50 \times 10^{-70 * * *}$ & D_37 & 0.028 & 0.122 & 0.23 & 0.8205 \\
\hline SDR5a & -1.762 & 0.091 & -19.45 & $1.67 \times 10^{-77 * * *}$ & D_39 & -0.447 & 0.095 & -4.72 & $2.48 \times 10^{-6 * * *}$ \\
\hline SDR5b & -1.439 & 0.065 & -22.04 & $7.11 \times 10^{-97 * * *}$ & D_40 & 0.258 & 0.120 & 2.16 & $2.48 \times 10^{-6 * * *}$ \\
\hline SDR6a & -1.588 & 0.171 & -9.30 & $3.51 \times 10^{-20 * * *}$ & D_41 & 0.263 & 0.120 & 2.18 & 0.0291 ** \\
\hline SDR6b & -1.131 & 0.180 & -6.29 & $4.00 \times 10^{-10 * * *}$ & D_42 & -1.241 & 0.767 & -1.62 & 0.1059 \\
\hline SDR7a & -1.186 & 0.198 & -6.01 & $2.26 \times 10^{-9 * * *}$ & D_43 & -1.671 & 0.755 & -2.21 & $0.0269^{* *}$ \\
\hline SDR7b & -1.566 & 0.181 & -8.63 & $1.17 \times 10^{-17 * * *}$ & D_44 & -2.991 & 0.765 & -3.91 & $9.55 \times 10^{-5 * * *}$ \\
\hline SDR8a & -1.638 & 0.207 & -7.92 & $3.94 \times 10^{-15 * * *}$ & D_45 & -1.951 & 0.785 & -2.49 & $0.0130 * *$ \\
\hline SDR8b & -1.219 & 0.219 & -5.56 & $3.12 \times 10^{-8 * * *}$ & D_46 & -3.521 & 0.711 & -4.96 & $7.83 \times 10^{-7 * * *}$ \\
\hline SDR9a & -1.235 & 0.250 & -4.95 & $8.22 \times 10^{-7 * * *}$ & D_47 & -4.054 & 0.710 & -5.71 & $1.31 \times 10^{-8 * * *}$ \\
\hline SDR9b & -1.627 & 0.225 & -7.22 & $7.47 \times 10^{-13 * * *}$ & D_48 & -3.267 & 0.716 & -4.56 & $5.40 \times 10^{-6 * * * *}$ \\
\hline SDRH1 & -0.950 & 0.156 & -6.10 & $1.23 \times 10^{-9 * * *}$ & D_49 & -3.902 & 0.715 & -5.46 & $5.50 \times 10^{-8 * * *}$ \\
\hline SDRH2 & -0.649 & 0.103 & -6.33 & $3.07 \times 10^{-10 * * *}$ & D_50 & -3.397 & 0.721 & -4.71 & $2.64 \times 10^{-6 * * *}$ \\
\hline SDRH3 & -1.021 & 0.114 & -8.95 & $7.89 \times 10^{-19 * * *}$ & D_51 & -4.621 & 0.773 & -5.98 & $2.59 \times 10^{-9} * * *$ \\
\hline
\end{tabular}




\begin{tabular}{|c|c|c|c|c|c|c|c|c|c|}
\hline Variables & Coefficient & Std. Error & t-Ratio & $p$-Value & Variables & Coefficient & Std. Error & t-Ratio & $p$-Value \\
\hline SDRH4 & -2.151 & 0.163 & -13.23 & $1.95 \times 10^{-38 * * *}$ & D_52 & -4.099 & 0.766 & -5.35 & $9.67 \times 10^{-8 * * *}$ \\
\hline SDRH5 & -5.594 & 0.707 & -7.91 & $4.17 \times 10^{-15 * * *}$ & D_53 & -4.570 & 0.737 & -6.20 & $6.77 \times 10^{-10 * * *}$ \\
\hline SDRH6 & -5.867 & 0.705 & -8.32 & $1.53 \times 10^{-16 * * *}$ & D_54 & -4.190 & 0.737 & -5.68 & $1.52 \times 10^{-8 * * *}$ \\
\hline SDRH7 & -6.242 & 0.726 & -8.60 & $1.56 \times 10^{-17 * * *}$ & D_55 & -4.325 & 0.752 & -5.75 & $1.01 \times 10^{-8 * * *}$ \\
\hline SDRH8 & -6.265 & 0.726 & -8.63 & $1.17 \times 10^{-17 * * *}$ & D_56 & -0.063 & 1.004 & -0.06 & 0.95 \\
\hline SDRH9 & -6.244 & 0.716 & -8.72 & $5.83 \times 10^{-18 * * *}$ & D_57 & -1.037 & 1.100 & -0.94 & 0.3459 \\
\hline D_2 & 0.168 & 1.089 & 0.15 & 0.8772 & D_58 & -1.202 & 1.002 & -1.20 & 0.2304 \\
\hline D_3 & 2.588 & 1.009 & 2.58 & $0.0101 * *$ & D_59 & -2.547 & 0.892 & -2.86 & $0.0043^{* * *}$ \\
\hline D_4 & -4.733 & 1.352 & -3.50 & $0.0005^{* * *}$ & D_60 & 1.716 & 0.979 & 1.75 & 0.0799 * \\
\hline D_5 & -0.903 & 0.724 & -1.25 & 0.2129 & D_61 & 0.104 & 0.960 & 0.11 & 0.9141 \\
\hline D_6 & -1.517 & 0.863 & -1.76 & $0.0789 *$ & D_62 & 0.439 & 0.920 & 0.48 & 0.6335 \\
\hline D_7 & -2.677 & 0.825 & -3.25 & $0.0012^{* * *}$ & D_63 & -4.105 & 0.758 & -5.42 & $6.70 \times 10^{-8 * * *}$ \\
\hline D_8 & -3.054 & 0.747 & -4.09 & $4.48 \times 10^{-5 * * *}$ & D_64 & -2.708 & 0.743 & -3.64 & $0.0003^{* * *}$ \\
\hline D_9 & -2.972 & 2.495 & -1.19 & 0.2336 & D_65 & -5.778 & 0.734 & -7.88 & $5.35 \times 10^{-15 * * *}$ \\
\hline D_10 & 0.860 & 0.814 & 1.06 & 0.2914 & D_66 & -6.768 & 0.726 & -9.33 & $2.71 \times 10^{-20 * * *}$ \\
\hline D_11 & -1.135 & 1.136 & -1.00 & 0.3177 & D_67 & -6.482 & 0.732 & -8.85 & $1.83 \times 10^{-18 * * *}$ \\
\hline D_12 & -1.771 & 0.745 & -2.38 & $0.0175^{* *}$ & D_68 & -5.432 & 0.723 & -7.51 & $8.83 \times 10^{-14 * * *}$ \\
\hline D_13 & -2.417 & 0.724 & -3.34 & $0.0009^{* * *}$ & D_69 & -6.482 & 0.732 & -8.85 & $1.83 \times 10^{-18 * * *}$ \\
\hline D_14 & -1.819 & 0.778 & -2.34 & $0.0194^{* *}$ & D_70 & -5.516 & 0.712 & -7.74 & $1.50 \times 10^{-14 * * *}$ \\
\hline D_15 & -2.832 & 0.741 & -3.83 & $0.0001^{* * *}$ & D_71 & -5.901 & 0.751 & -7.86 & $6.11 \times 10^{-15 * * *}$ \\
\hline D_16 & -4.559 & 0.755 & -6.04 & $1.86 \times 10^{-9} * * *$ & D_72 & -6.469 & 0.733 & -8.83 & $2.26 \times 10^{-18 * * *}$ \\
\hline D_17 & -5.661 & 0.895 & -6.33 & $3.06 \times 10^{-10 * * *}$ & D_73 & -5.550 & 0.711 & -7.81 & $9.37 \times 10^{-15 * * *}$ \\
\hline D_18 & -3.597 & 0.750 & -4.79 & $1.76 \times 10^{-6 * * *}$ & D_74 & -5.763 & 0.711 & -8.11 & $8.68 \times 10^{-16 * * *}$ \\
\hline D_19 & -1.936 & 0.715 & -2.71 & $0.0068^{* * *}$ & D_75 & -4.973 & 0.712 & -6.98 & $3.85 \times 10^{-12 * * *}$ \\
\hline D_20 & -2.982 & 0.713 & -4.18 & $3.03 \times 10^{-5 * * *}$ & D_76 & -5.205 & 0.714 & -7.30 & $4.25 \times 10^{-13 * * *}$ \\
\hline
\end{tabular}

Note: ${ }^{* * *}, * *,{ }^{*}$ indicate the level of significance $1 \%, 5 \%$ or $10 \%$, respectively.

\begin{tabular}{cc}
\hline Statistics of Model & Value \\
\hline Sum of squared residuals & 7115.081 \\
\hline S.E. of regression & 1.857572 \\
\hline R-squared & 0.872745 \\
\hline Adjusted R-squared & 0.866019 \\
\hline F (109.2062) & 129.7407 \\
\hline$p$-value (F) & 0.00000 \\
\hline Farrar-Glauber multicollinearity & Negative \\
\hline
\end{tabular}


Appendix A.2. Econometric Model for Variables Based on Decree No. 540/2002 Coll

\begin{tabular}{|c|c|c|c|c|c|c|c|c|c|}
\hline Variables & Coefficient & Std. Error & t-Ratio & $p$-Value & Variables & Coefficient & Std. Error & t-Ratio & $p$-Value \\
\hline Const & 11.388 & 0.290 & 39.20 & $1.10 \times 10^{-251 * * *}$ & D_21 & -6.656 & 0.292 & -22.78 & $1.26 \times 10^{-102 * * *}$ \\
\hline K1 & -0.478 & 0.051 & -9.33 & $2.57 \times 10^{-20 * * *}$ & D_22 & -5.932 & 0.292 & -20.31 & $1.01 \times 10^{-83 * * *}$ \\
\hline $\mathrm{K} 2$ & 0.266 & 0.051 & 5.17 & $2.51 \times 10^{-7 * * *}$ & D_23 & -5.847 & 0.305 & -19.16 & $2.09 \times 10^{-75 * * *}$ \\
\hline $\mathrm{K} 3$ & 1.105 & 0.055 & 19.96 & $3.48 \times 10^{-81 * * *}$ & D_24 & -4.501 & 0.312 & -14.43 & $5.03 \times 10^{-45 * * *}$ \\
\hline K4 & -0.717 & 0.051 & -14.03 & $8.36 \times 10^{-43 * * *}$ & D_25 & -4.135 & 0.309 & -13.38 & $3.12 \times 10^{-39 * * *}$ \\
\hline K5 & -0.167 & 0.049 & -3.41 & $0.0007^{* * *}$ & D_26 & -4.832 & 0.304 & -15.88 & $1.13 \times 10^{-53 * * *}$ \\
\hline K6 & -0.451 & 0.055 & -8.18 & $4.77 \times 10^{-16 * * *}$ & D_27 & -5.114 & 0.312 & -16.37 & $9.80 \times 10^{-57 * * *}$ \\
\hline K7 & -1.196 & 0.058 & -20.59 & $7.54 \times 10^{-86 * * *}$ & D_28 & -4.120 & 0.310 & -13.29 & $9.34 \times 10^{-39 * * *}$ \\
\hline K8 & -1.529 & 0.075 & -20.25 & $2.52 \times 10^{-83 * * *}$ & D_29 & -4.746 & 0.308 & -15.41 & $8.94 \times 10^{-51 * * *}$ \\
\hline K9 & -1.340 & 0.089 & -15.08 & $7.81 \times 10^{-49 * * *}$ & D_30 & -4.500 & 0.311 & -14.49 & $2.22 \times 10^{-45 * * *}$ \\
\hline SDR1 & -0.810 & 0.034 & -23.90 & $1.23 \times 10^{-111 * * *}$ & D_31 & -5.119 & 0.310 & -16.49 & $1.66 \times 10^{-57 * * *}$ \\
\hline SDR2a & -1.477 & 0.128 & -11.58 & $4.41 \times 10^{-30 * * *}$ & D_32 & -5.508 & 0.310 & -17.76 & $9.37 \times 10^{-66 * * *}$ \\
\hline SDR2b & -0.796 & 0.124 & -6.42 & $1.67 \times 10^{-10 * * *}$ & D_33 & -4.314 & 0.320 & -13.48 & $1.00 \times 10^{-39 * * *}$ \\
\hline SDR3a & -0.940 & 0.158 & -5.96 & $2.98 \times 10^{-9 * * *}$ & D_34 & -5.236 & 0.334 & -15.68 & $2.04 \times 10^{-52 * * *}$ \\
\hline SDR3b & -1.282 & 0.143 & -8.98 & $5.74 \times 10^{-19 * * *}$ & D_35 & -5.188 & 0.334 & -15.51 & $2.07 \times 10^{-51 * * *}$ \\
\hline SDR4a & -1.725 & 0.039 & -43.84 & $3.35 \times 10^{-297 * * *}$ & D_36 & -5.916 & 0.402 & -14.73 & $9.01 \times 10^{-47 * * *}$ \\
\hline SDR4b & -1.330 & 0.054 & -24.83 & $2.56 \times 10^{-119 * * *}$ & D_37 & -0.065 & 0.125 & -0.52 & 0.6046 \\
\hline SDR5a & -1.458 & 0.055 & -26.52 & $1.31 \times 10^{-133 * * *}$ & D_39 & 0.301 & 0.124 & 2.42 & $0.0157^{* *}$ \\
\hline SDR5b & -1.564 & 0.039 & -40.19 & $2.67 \times 10^{-261 * * *}$ & D_40 & 0.035 & 0.172 & 0.20 & 0.8412 \\
\hline SDR6a & -1.295 & 0.146 & -8.88 & $1.39 \times 10^{-18 * * *}$ & D_41 & 0.048 & 0.173 & 0.28 & 0.7813 \\
\hline SDR6b & -0.290 & 0.143 & -2.03 & 0.0425 ** & D_42 & -3.005 & 0.356 & -8.43 & $6.20 \times 10^{-17 * * *}$ \\
\hline SDR7a & -0.351 & 0.192 & -1.83 & $0.0680 *$ & D_43 & -3.764 & 0.345 & -10.90 & $6.21 \times 10^{-27 * * *}$ \\
\hline $\mathrm{SDR} 7 \mathrm{~b}$ & -1.199 & 0.203 & -5.90 & $4.38 \times 10^{-9 * * *}$ & D_44 & -4.283 & 0.351 & -12.19 & $4.57 \times 10^{-33 * * *}$ \\
\hline SDR8a & -1.193 & 0.231 & -5.15 & $2.80 \times 10^{-7 * * *}$ & D_45 & -3.966 & 0.317 & -12.52 & $1.09 \times 10^{-34 * * *}$ \\
\hline SDR8b & -0.355 & 0.225 & -1.58 & 0.1142 & D_46 & -5.007 & 0.305 & -16.41 & $5.49 \times 10^{-57 * * *}$ \\
\hline SDR9a & -0.353 & 0.287 & -1.23 & 0.2185 & D_47 & -5.790 & 0.290 & -19.97 & $2.85 \times 10^{-81 * * *}$ \\
\hline SDR9b & -1.192 & 0.300 & -3.98 & $7.27 \times 10^{-5 * * *}$ & D_48 & -5.433 & 0.308 & -17.62 & $7.20 \times 10^{-65 * * *}$ \\
\hline SDRH1 & -0.726 & 0.100 & -7.24 & $6.46 \times 10^{-13 * * *}$ & D_49 & -6.166 & 0.308 & -20.00 & $1.73 \times 10^{-81 * * *}$ \\
\hline SDRH2 & -1.032 & 0.056 & -18.40 & $3.75 \times 10^{-70 * * *}$ & D_50 & -5.372 & 0.306 & -17.55 & $2.19 \times 10^{-64 * * *}$ \\
\hline SDRH3 & -1.441 & 0.059 & -24.48 & $2.13 \times 10^{-116 * * *}$ & D_51 & -6.181 & 0.305 & -20.27 & $1.76 \times 10^{-83 * * *}$ \\
\hline SDRH4 & -2.489 & 0.105 & -23.73 & $2.70 \times 10^{-110 * * *}$ & D_52 & -5.863 & 0.310 & -18.89 & $1.65 \times 10^{-73 * * *}$ \\
\hline SDRH5 & -8.568 & 0.305 & -28.08 & $3.63 \times 10^{-147 * * *}$ & D_53 & -5.939 & 0.307 & -19.37 & $5.84 \times 10^{-77 * * *}$ \\
\hline SDRH6 & -8.788 & 0.309 & -28.43 & $2.75 \times 10^{-150 * * *}$ & D_54 & -6.528 & 0.304 & -21.47 & $1.92 \times 10^{-92 * * *}$ \\
\hline SDRH7 & -9.368 & 0.372 & -25.18 & $3.52 \times 10^{-122 * * *}$ & D_55 & -5.688 & 0.377 & -15.09 & $7.29 \times 10^{-49 * * *}$ \\
\hline SDRH8 & -9.379 & 0.372 & -25.21 & $1.86 \times 10^{-122 * * *}$ & D_56 & -2.881 & 0.625 & -4.61 & $4.28 \times 10^{-6 * * *}$ \\
\hline SDRH9 & -9.394 & 0.337 & -27.89 & $1.72 \times 10^{-145 * * *}$ & D_57 & -3.920 & 0.736 & -5.32 & $1.13 \times 10^{-7 * * *}$ \\
\hline D_2 & 0.080 & 0.527 & 0.15 & 0.8801 & D_58 & -4.769 & 0.615 & -7.76 & $1.33 \times 10^{-14 * * *}$ \\
\hline D_3 & 1.146 & 0.713 & 1.61 & 0.1081 & D_59 & -5.631 & 0.381 & -14.78 & $4.70 \times 10^{-47 * * *}$ \\
\hline D_4 & -5.318 & 0.331 & -16.09 & $6.10 \times 10^{-55 * * *}$ & D_60 & -0.498 & 0.814 & -0.61 & 0.5409 \\
\hline D_5 & -4.001 & 0.401 & -9.98 & $6.13 \times 10^{-23 * * *}$ & D_61 & -1.985 & 0.827 & -2.40 & $0.0165^{* *}$ \\
\hline D_6 & -2.382 & 0.335 & -7.11 & $1.54 \times 10^{-12 * * *}$ & D_62 & -3.620 & 0.403 & -8.99 & $5.72 \times 10^{-19 * * *}$ \\
\hline D_7 & -2.785 & 0.370 & -7.53 & $7.33 \times 10^{-14 * * *}$ & D_63 & -7.477 & 0.368 & -20.29 & $1.28 \times 10^{-83 * * *}$ \\
\hline
\end{tabular}




\begin{tabular}{cccccccccc}
\hline Variables & Coefficient & Std. Error & t-Ratio & $p$-Value & Variables & Coefficient & Std. Error & t-Ratio & $p$-Value \\
\hline D_8 & -3.116 & 0.305 & -10.21 & $6.56 \times 10^{-24 * * *}$ & D_64 & -6.128 & 0.321 & -19.08 & $7.48 \times 10^{-75 * * *}$ \\
\hline D_9 & -0.114 & 0.576 & -0.20 & 0.8428 & D_65 & -7.536 & 0.363 & -20.74 & $5.97 \times 10^{-87 * * *}$ \\
\hline D_10 & -0.311 & 0.357 & -0.87 & 0.3843 & D_66 & -9.200 & 0.409 & -22.51 & $1.57 \times 10^{-100 * * *}$ \\
\hline D_11 & -1.628 & 0.328 & -4.97 & $7.41 \times 10^{-7 * * *}$ & D_67 & -9.340 & 0.354 & -26.40 & $1.43 \times 10^{-132 * * *}$ \\
\hline D_12 & -2.108 & 0.324 & -6.51 & $9.56 \times 10^{-11 * * *}$ & D_68 & -8.190 & 0.340 & -24.11 & $2.30 \times 10^{-113 * * *}$ \\
\hline D_13 & -3.037 & 0.299 & -10.15 & $1.15 \times 10^{-23 * * *}$ & D_69 & -9.204 & 0.379 & -24.30 & $6.67 \times 10^{-115 * * *}$ \\
\hline D_14 & -2.177 & 0.321 & -6.79 & $1.48 \times 10^{-11 * * *}$ & D_70 & -7.818 & 0.348 & -22.48 & $2.90 \times 10^{-100 * * *}$ \\
\hline D_15 & -2.964 & 0.310 & -9.58 & $2.81 \times 10^{-21 * * *}$ & D_71 & -8.260 & 0.350 & -23.59 & $3.67 \times 10^{-109 * * *}$ \\
\hline D_16 & -4.725 & 0.326 & -14.49 & $2.30 \times 10^{-45 * * *}$ & D_72 & -9.152 & 0.374 & -24.50 & $1.56 \times 10^{-116 * * *}$ \\
\hline D_17 & -5.996 & 0.309 & -19.42 & $2.62 \times 10^{-77 * * *}$ & D_73 & -7.901 & 0.319 & -24.78 & $6.54 \times 10^{-119 * * *}$ \\
\hline D_18 & -4.619 & 0.312 & -14.80 & $3.38 \times 10^{-47 * * *}$ & D_74 & -7.895 & 0.320 & -24.68 & $4.88 \times 10^{-118 * * *}$ \\
\hline D_19 & -3.947 & 0.312 & -12.63 & $2.70 \times 10^{-35 * * *}$ & D_75 & -7.534 & 0.328 & -22.99 & $2.41 \times 10^{-104 * * *}$ \\
\hline D_20 & -5.022 & 0.304 & -16.51 & $1.30 \times 10^{-57 * * *}$ & D_76 & -7.517 & 0.329 & -22.87 & $2.25 \times 10^{-103 * * *}$ \\
\hline
\end{tabular}

Note: ${ }^{* * *}, * *,{ }^{*}$ indicate the level of significance $1 \%, 5 \%$ or $10 \%$, respectively.

\begin{tabular}{cc}
\hline Statistics of Model & Value \\
\hline Sum of squared residuals & 6344.251 \\
\hline S.E. of regression & 1.754066 \\
\hline R-squared & 0.945994 \\
\hline Adjusted R-squared & 0.943139 \\
\hline F (109.2062) & 331.3671 \\
\hline$p$-value (F) & 0.00000 \\
\hline Farrar-Glauber multicollinearity & Negative
\end{tabular}

Appendix A.3. Econometric Model for Variables Based on Decree No. 3/2008 Coll

\begin{tabular}{cccccccccc}
\hline Variables & Coefficient & Std. Error & t-Ratio & $p$-Value & Variables & Coefficient & Std. Error & t-Ratio & $p$-Value \\
\hline Const & 13.319 & 0.335 & 39.80 & $1.51 \times 10^{-257 * * *}$ & D_21 & -7.667 & 0.337 & -22.78 & $1.19 \times 10^{-102 * * *}$ \\
\hline K1 & -0.557 & 0.059 & -9.41 & $1.30 \times 10^{-20 * * *}$ & D_22 & -6.832 & 0.336 & -20.31 & $9.82 \times 10^{-84 * * *}$ \\
\hline K2 & 0.294 & 0.060 & 4.92 & $9.34 \times 10^{-7 * * *}$ & D_23 & -6.730 & 0.352 & -19.12 & $3.56 \times 10^{-75 * * *}$ \\
\hline K3 & 1.258 & 0.064 & 19.68 & $3.56 \times 10^{-79 * * *}$ & D_24 & -5.186 & 0.359 & -14.44 & $4.52 \times 10^{-45 * * *}$ \\
\hline K4 & -0.831 & 0.059 & -14.06 & $5.79 \times 10^{-43 * * *}$ & D_25 & -4.764 & 0.356 & -13.39 & $2.99 \times 10^{-39 * * *}$ \\
\hline K5 & -0.208 & 0.057 & -3.68 & $0.0002^{* * *}$ & D_26 & -5.568 & 0.350 & -15.90 & $8.70 \times 10^{-54 * * *}$ \\
\hline K6 & -0.527 & 0.064 & -8.30 & $1.81 \times 10^{-16 * * *}$ & D_27 & -5.893 & 0.359 & -16.40 & $6.54 \times 10^{-57 * * *}$ \\
\hline K7 & -1.381 & 0.067 & -20.58 & $9.63 \times 10^{-86 * * *}$ & D_28 & -4.749 & 0.357 & -13.32 & $7.10 \times 10^{-39 * * *}$ \\
\hline K8 & -1.755 & 0.087 & -20.23 & $3.50 \times 10^{-83 * * *}$ & D_29 & -5.470 & 0.355 & -15.42 & $7.16 \times 10^{-51 * * *}$ \\
\hline K9 & -1.533 & 0.103 & -14.95 & $4.74 \times 10^{-48 * * *}$ & D_30 & -5.189 & 0.357 & -14.52 & $1.50 \times 10^{-45 * * *}$ \\
\hline SDR1 & -0.932 & 0.039 & -24.06 & $6.21 \times 10^{-113 * * *}$ & D_31 & -5.900 & 0.357 & -16.51 & $1.22 \times 10^{-57 * * *}$ \\
\hline SDR2a & -1.676 & 0.150 & -11.14 & $4.91 \times 10^{-28 * * *}$ & D_32 & -6.351 & 0.358 & -17.74 & $1.16 \times 10^{-65 * * *}$ \\
\hline SDR2b & -0.908 & 0.144 & -6.30 & $3.63 \times 10^{-10 * * *}$ & D_33 & -4.975 & 0.368 & -13.51 & $6.12 \times 10^{-40 * * *}$ \\
\hline SDR3a & -1.073 & 0.181 & -5.94 & $3.26 \times 10^{-9} * * *$ & D_34 & -6.055 & 0.384 & -15.76 & $6.42 \times 10^{-53 * * *}$ \\
\hline SDR3b & -1.518 & 0.154 & -9.88 & $1.63 \times 10^{-22 * * *}$ & D_35 & -6.000 & 0.385 & -15.58 & $7.95 \times 10^{-52 * * *}$ \\
\hline SDR4a & -1.984 & 0.045 & -44.12 & $5.24 \times 10^{-300 * * *}$ & D_36 & -6.842 & 0.464 & -14.76 & $5.93 \times 10^{-47 * * *}$ \\
\hline SDR4b & -1.536 & 0.061 & -25.14 & $6.51 \times 10^{-122 * * *}$ & D_37 & -0.075 & 0.144 & -0.52 & 0.6042 \\
\hline
\end{tabular}




\begin{tabular}{|c|c|c|c|c|c|c|c|c|c|}
\hline Variables & Coefficient & Std. Error & t-Ratio & $p$-Value & Variables & Coefficient & Std. Error & t-Ratio & $p$-Value \\
\hline SDR5a & -1.682 & 0.063 & -26.85 & $2.14 \times 10^{-136 * * *}$ & D_39 & 0.351 & 0.144 & 2.43 & 0.0152 ** \\
\hline SDR5b & -1.799 & 0.045 & -40.42 & $1.30 \times 10^{-263 * * *}$ & D_40 & 0.039 & 0.199 & 0.20 & 0.8435 \\
\hline SDR6a & -1.383 & 0.161 & -8.61 & $1.43 \times 10^{-17 * * *}$ & D_41 & 0.056 & 0.199 & 0.28 & 0.78 \\
\hline SDR6b & -0.242 & 0.156 & -1.55 & 0.1219 & D_42 & -3.462 & 0.409 & -8.47 & $4.46 \times 10^{-17 * * *}$ \\
\hline SDR7a & -0.310 & 0.215 & -1.44 & 0.1492 & D_43 & -4.331 & 0.396 & -10.94 & $4.24 \times 10^{-27 * * *}$ \\
\hline SDR7b & -1.270 & 0.230 & -5.52 & $3.73 \times 10^{-8 * * *}$ & D_44 & -4.923 & 0.405 & -12.16 & $6.32 \times 10^{-33 * * *}$ \\
\hline SDR8a & -1.262 & 0.263 & -4.81 & $1.64 \times 10^{-6 * * *}$ & D_45 & -4.567 & 0.365 & -12.52 & $9.93 \times 10^{-35 * * *}$ \\
\hline SDR8b & -0.314 & 0.253 & -1.24 & 0.2149 & D_46 & -5.770 & 0.352 & -16.41 & $5.53 \times 10^{-57 * * *}$ \\
\hline SDR9a & -0.312 & 0.326 & -0.96 & 0.3388 & D_47 & -6.667 & 0.334 & -19.97 & $2.84 \times 10^{-81 * * *}$ \\
\hline SDR9b & -1.263 & 0.343 & -3.68 & $0.0002^{* * *}$ & D_48 & -6.267 & 0.355 & -17.66 & $3.91 \times 10^{-65 * * *}$ \\
\hline SDRH1 & -0.829 & 0.115 & -7.22 & $7.46 \times 10^{-13 * * *}$ & D_49 & -7.110 & 0.354 & -20.06 & $6.21 \times 10^{-82 * * *}$ \\
\hline SDRH2 & -1.188 & 0.064 & -18.46 & $1.59 \times 10^{-70 * * *}$ & D_50 & -6.191 & 0.352 & -17.57 & $1.55 \times 10^{-64 * * *}$ \\
\hline SDRH3 & -1.659 & 0.067 & -24.61 & $1.82 \times 10^{-117 * * *}$ & D_51 & -7.123 & 0.351 & -20.30 & $1.16 \times 10^{-83 * * *}$ \\
\hline SDRH4 & -2.863 & 0.120 & -23.84 & $3.74 \times 10^{-111 * * *}$ & D_52 & -6.757 & 0.357 & -18.93 & $8.27 \times 10^{-74 * * *}$ \\
\hline SDRH5 & -9.870 & 0.352 & -28.06 & $4.86 \times 10^{-147 * * *}$ & D_53 & -6.843 & 0.353 & -19.40 & $3.58 \times 10^{-77 * * *}$ \\
\hline SDRH6 & -10.124 & 0.356 & -28.43 & $2.84 \times 10^{-150 * * *}$ & D_54 & -7.526 & 0.350 & -21.53 & $6.70 \times 10^{-93 * * *}$ \\
\hline SDRH7 & -10.899 & 0.426 & -25.60 & $8.90 \times 10^{-126 * * *}$ & D_55 & -6.549 & 0.430 & -15.24 & $9.29 \times 10^{-50 * * *}$ \\
\hline SDRH8 & -10.911 & 0.426 & -25.63 & $4.83 \times 10^{-126 * * *}$ & D_56 & -3.314 & 0.714 & -4.64 & $3.73 \times 10^{-6 * * *}$ \\
\hline SDRH9 & -10.929 & 0.385 & -28.41 & $3.92 \times 10^{-150 * * *}$ & D_57 & -4.523 & 0.844 & -5.36 & $9.19 \times 10^{-8 * * *}$ \\
\hline D_2 & 0.097 & 0.606 & 0.16 & 0.8725 & D_58 & -5.495 & 0.704 & -7.80 & $9.42 \times 10^{-15 * * *}$ \\
\hline D_3 & 1.315 & 0.821 & 1.60 & 0.1092 & D_59 & -6.487 & 0.438 & -14.80 & $3.33 \times 10^{-47 * * *}$ \\
\hline D_4 & -6.136 & 0.381 & -16.10 & $5.04 \times 10^{-55 * * *}$ & D_60 & -0.590 & 0.934 & -0.63 & 0.5273 \\
\hline D_5 & -4.618 & 0.462 & -9.99 & $5.67 \times 10^{-23 * * *}$ & D_61 & -2.301 & 0.948 & -2.43 & $0.0154^{* *}$ \\
\hline D_6 & -2.743 & 0.386 & -7.11 & $1.60 \times 10^{-12 * * *}$ & D_62 & -4.179 & 0.463 & -9.04 & $3.67 \times 10^{-19 * * *}$ \\
\hline D_7 & -3.215 & 0.427 & -7.53 & $7.47 \times 10^{-14 * * *}$ & D_63 & -8.609 & 0.424 & -20.32 & $7.75 \times 10^{-84 * * *}$ \\
\hline D_8 & -3.592 & 0.351 & -10.22 & $5.92 \times 10^{-24 * * *}$ & D_64 & -7.068 & 0.369 & -19.17 & $1.68 \times 10^{-75 * * *}$ \\
\hline D_9 & -0.134 & 0.660 & -0.20 & 0.8397 & D_65 & -8.695 & 0.419 & -20.75 & $4.98 \times 10^{-87 * * *}$ \\
\hline D_10 & -0.355 & 0.409 & -0.87 & 0.3857 & D_66 & -10.606 & 0.471 & -22.52 & $1.44 \times 10^{-100 * * *}$ \\
\hline D_11 & -1.870 & 0.378 & -4.95 & $7.86 \times 10^{-7 * * *}$ & D_67 & -10.771 & 0.383 & -28.11 & $1.73 \times 10^{-147 * * *}$ \\
\hline D_12 & -2.424 & 0.377 & -6.43 & $1.54 \times 10^{-10 * * *}$ & D_68 & -9.444 & 0.390 & -24.19 & $5.31 \times 10^{-114 * * *}$ \\
\hline D_13 & -3.499 & 0.345 & -10.14 & $1.26 \times 10^{-23 * * *}$ & D_69 & -10.615 & 0.434 & -24.46 & $3.12 \times 10^{-116 * * *}$ \\
\hline D_14 & -2.502 & 0.368 & -6.79 & $1.42 \times 10^{-11 * * *}$ & D_70 & -9.016 & 0.400 & -22.55 & $8.37 \times 10^{-101 * * *}$ \\
\hline D_15 & -3.417 & 0.357 & -9.58 & $2.80 \times 10^{-21 * * *}$ & D_71 & -9.527 & 0.402 & -23.70 & $4.88 \times 10^{-110 * * *}$ \\
\hline D_16 & -5.432 & 0.377 & -14.41 & $6.71 \times 10^{-45 * * *}$ & D_72 & -10.553 & 0.430 & -24.57 & $4.00 \times 10^{-117 * * *}$ \\
\hline D_17 & -6.896 & 0.356 & -19.34 & $9.60 \times 10^{-77 * * *}$ & D_73 & -9.104 & 0.367 & -24.80 & $4.89 \times 10^{-119 * * *}$ \\
\hline D_18 & -5.323 & 0.359 & -14.82 & $2.58 \times 10^{-47 * * *}$ & D_74 & -9.098 & 0.368 & -24.70 & $3.31 \times 10^{-118 * * *}$ \\
\hline D_19 & -4.553 & 0.359 & -12.68 & $1.65 \times 10^{-35 * * *}$ & D_75 & -8.682 & 0.377 & -23.04 & $1.04 \times 10^{-104 * * *}$ \\
\hline D_20 & -5.792 & 0.350 & -16.54 & $8.29 \times 10^{-58 * * *}$ & D_76 & -8.663 & 0.378 & -22.91 & $1.06 \times 10^{-103 * * *}$ \\
\hline
\end{tabular}

Note: ${ }^{* * *},{ }^{* *}$ indicate the level of significance $1 \%, 5 \%$ respectively. 


\begin{tabular}{cc}
\hline Statistics of Model & Value \\
\hline Sum of squared residuals & 6323.629 \\
\hline S.E. of regression & 1.751212 \\
\hline R-squared & 0.946252 \\
\hline Adjusted R-squared & 0.943411 \\
\hline F (109.2062) & 333.0493 \\
\hline$p$-value (F) & 0.00000 \\
\hline Farrar-Glauber multicollinearity & Negative \\
\hline
\end{tabular}

Appendix A.4. Econometric Model for Variables Based on Decree No. 441/2013 Coll

\begin{tabular}{|c|c|c|c|c|c|c|c|c|c|}
\hline Variables & Coefficient & Std. Error & t-Ratio & $p$-Value & Variables & Coefficient & Std. Error & t-Ratio & $p$-Value \\
\hline Const & 15.275 & 0.384 & 39.80 & $1.60 \times 10^{-257 * * *}$ & D_21 & -8.785 & 0.386 & -22.76 & $1.75 \times 10^{-102 * * *}$ \\
\hline K1 & -0.644 & 0.068 & -9.53 & $4.17 \times 10^{-21 * * *}$ & D_22 & -7.823 & 0.386 & -20.27 & $1.82 \times 10^{-83 * * *}$ \\
\hline K2 & 0.335 & 0.068 & 4.91 & $9.83 \times 10^{-7 * * *}$ & D_23 & -7.705 & 0.404 & -19.07 & $8.12 \times 10^{-75 * * *}$ \\
\hline K3 & 1.436 & 0.073 & 19.66 & $5.54 \times 10^{-79 * * *}$ & D_24 & -5.940 & 0.412 & -14.42 & $5.32 \times 10^{-45 * * *}$ \\
\hline K4 & -0.954 & 0.067 & -14.16 & $1.73 \times 10^{-43 * * *}$ & D_25 & -5.453 & 0.408 & -13.36 & $4.20 \times 10^{-39 * * *}$ \\
\hline K5 & -0.242 & 0.064 & -3.76 & $0.0002^{* * *}$ & D_26 & -6.372 & 0.402 & -15.86 & $1.56 \times 10^{-53 * * *}$ \\
\hline K6 & -0.613 & 0.073 & -8.45 & $5.54 \times 10^{-17 * * *}$ & D_27 & -6.744 & 0.413 & -16.35 & $1.42 \times 10^{-56 * * *}$ \\
\hline K7 & -1.594 & 0.077 & -20.81 & $1.89 \times 10^{-87 * * *}$ & D_28 & -5.437 & 0.409 & -13.28 & $1.10 \times 10^{-38 * * *}$ \\
\hline K8 & -2.020 & 0.099 & -20.44 & $9.67 \times 10^{-85 * * *}$ & D_29 & -6.260 & 0.407 & -15.38 & $1.27 \times 10^{-50 * * *}$ \\
\hline K9 & -1.779 & 0.117 & -15.18 & $2.05 \times 10^{-49 * * *}$ & D_30 & -5.941 & 0.410 & -14.49 & $2.31 \times 10^{-45 * * *}$ \\
\hline SDR1 & -1.069 & 0.045 & -24.01 & $1.67 \times 10^{-112 * * *}$ & D_31 & -6.750 & 0.410 & -16.47 & $2.52 \times 10^{-57 * * *}$ \\
\hline SDR2a & -1.928 & 0.173 & -11.17 & $3.78 \times 10^{-28 * * *}$ & D_32 & -7.270 & 0.411 & -17.69 & $2.45 \times 10^{-65 * * *}$ \\
\hline SDR2b & -1.038 & 0.165 & -6.29 & $3.97 \times 10^{-10 * * *}$ & D_33 & -5.696 & 0.422 & -13.49 & $8.62 \times 10^{-40 * * *}$ \\
\hline SDR3a & -1.229 & 0.207 & -5.94 & $3.31 \times 10^{-9 * * *}$ & D_34 & -6.936 & 0.439 & -15.79 & $4.26 \times 10^{-53 * * *}$ \\
\hline SDR3b & -1.748 & 0.177 & -9.87 & $1.83 \times 10^{-22 * * *}$ & D_35 & -6.870 & 0.443 & -15.53 & $1.71 \times 10^{-51 * * *}$ \\
\hline SDR4a & -2.279 & 0.052 & -44.20 & $8.59 \times 10^{-301 * * *}$ & D_36 & -7.826 & 0.533 & -14.68 & $1.82 \times 10^{-46 * * *}$ \\
\hline SDR4b & -1.757 & 0.070 & -25.06 & $3.35 \times 10^{-121 * * *}$ & D_37 & -0.085 & 0.165 & -0.51 & 0.6083 \\
\hline SDR5a & -1.923 & 0.072 & -26.77 & $9.50 \times 10^{-136 * * *}$ & D_39 & 0.400 & 0.166 & 2.42 & $0.0158^{* *}$ \\
\hline SDR5b & -2.068 & 0.051 & -40.50 & $2.12 \times 10^{-264 * * *}$ & D_40 & 0.043 & 0.229 & 0.19 & 0.8518 \\
\hline SDR6a & -1.598 & 0.183 & -8.72 & $5.59 \times 10^{-18 * * *}$ & D_41 & 0.062 & 0.229 & 0.27 & 0.7883 \\
\hline SDR6b & -0.271 & 0.178 & -1.52 & 0.1294 & D_42 & -3.974 & 0.468 & -8.49 & $3.84 \times 10^{-17 * * *}$ \\
\hline SDR7a & -0.352 & 0.247 & -1.43 & 0.154 & D_43 & -4.964 & 0.455 & -10.92 & $5.14 \times 10^{-27 * * *}$ \\
\hline SDR7b & -1.463 & 0.264 & -5.55 & $3.22 \times 10^{-8 * * *}$ & D_44 & -5.638 & 0.463 & -12.16 & $6.29 \times 10^{-33 * * *}$ \\
\hline SDR8a & -1.453 & 0.301 & -4.82 & $1.52 \times 10^{-6 * * *}$ & D_45 & -5.229 & 0.419 & -12.48 & $1.71 \times 10^{-34 * * *}$ \\
\hline SDR8b & -0.357 & 0.291 & -1.23 & 0.2203 & D_46 & -6.615 & 0.403 & -16.43 & $4.35 \times 10^{-57 * * *}$ \\
\hline SDR9a & -0.354 & 0.376 & -0.94 & 0.3461 & D_47 & -7.638 & 0.383 & -19.95 & $4.45 \times 10^{-81 * * *}$ \\
\hline SDR9b & -1.455 & 0.394 & -3.69 & $0.0002^{* * *}$ & D_48 & -7.178 & 0.407 & -17.63 & $6.85 \times 10^{-65 * * *}$ \\
\hline SDRH1 & -0.956 & 0.132 & -7.22 & $7.14 \times 10^{-13 * * *}$ & D_49 & -8.145 & 0.407 & -20.03 & $1.15 \times 10^{-81 * * *}$ \\
\hline SDRH2 & -1.367 & 0.074 & -18.44 & $2.17 \times 10^{-70 * * *}$ & D_50 & -7.086 & 0.404 & -17.53 & $3.11 \times 10^{-64 * * *}$ \\
\hline SDRH3 & -1.905 & 0.078 & -24.49 & $1.95 \times 10^{-116 * * *}$ & D_51 & -8.157 & 0.403 & -20.27 & $2.00 \times 10^{-83 * * *}$ \\
\hline SDRH4 & -3.290 & 0.138 & -23.78 & $1.14 \times 10^{-110 * * *}$ & D_52 & -7.734 & 0.410 & -18.88 & $1.98 \times 10^{-73 * * *}$ \\
\hline SDRH5 & -11.313 & 0.403 & -28.05 & $6.47 \times 10^{-147 * * *}$ & D_53 & -7.830 & 0.405 & -19.35 & $8.88 \times 10^{-77 * * *}$ \\
\hline SDRH6 & -11.605 & 0.408 & -28.41 & $3.85 \times 10^{-150 * * *}$ & D_54 & -8.617 & 0.401 & -21.50 & $1.05 \times 10^{-92 * * *}$ \\
\hline
\end{tabular}




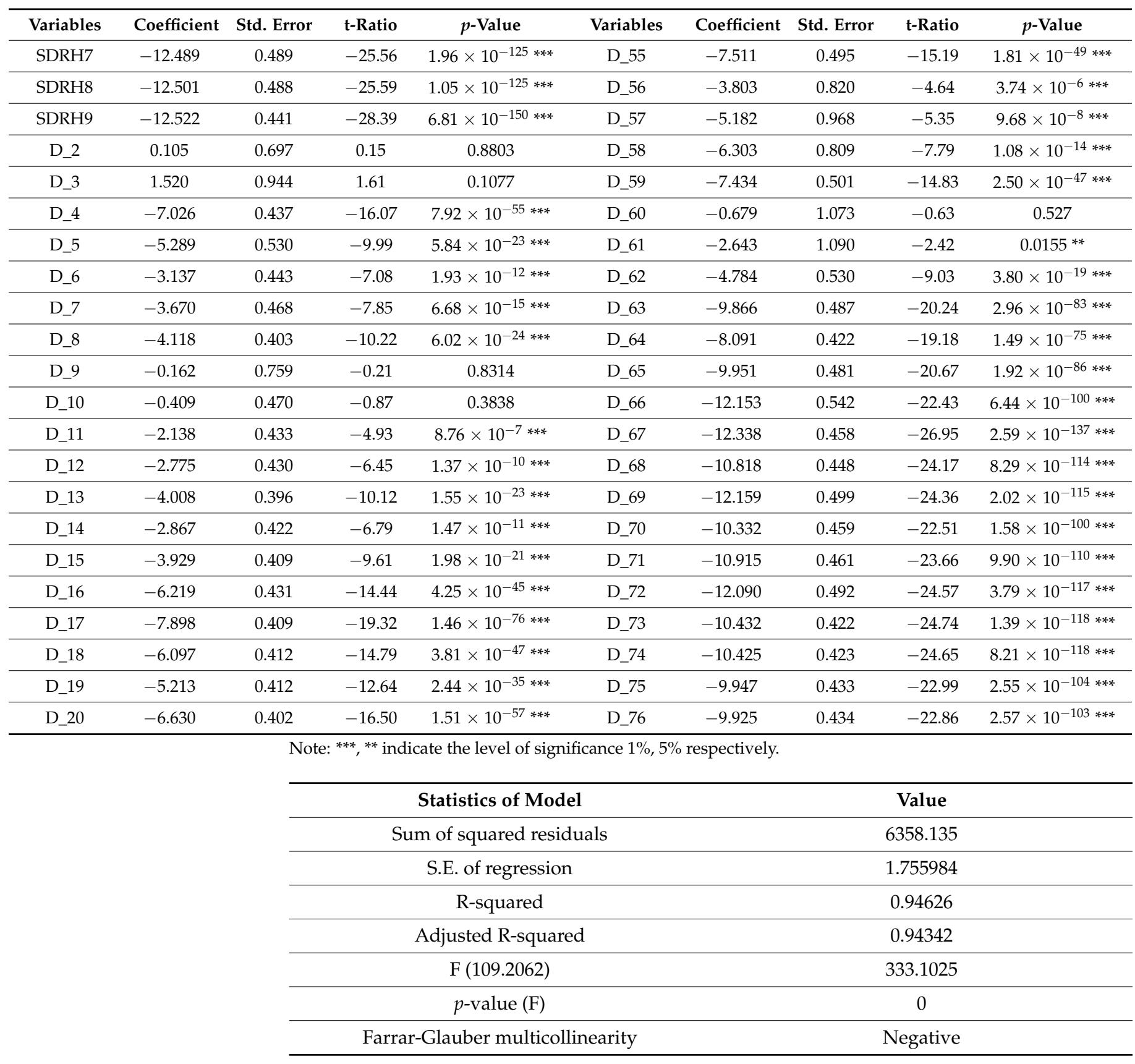

\section{References}

1. Chesworth, W. (Ed.) Encyclopedia of Soil Science; Encyclopedia of Earth Sciences Series; Springer: Dordrecht, The Netherlands, 2008; ISBN 978-1-4020-3994-2.

2. Pimentel, D.; Harvey, C.; Resosudarmo, P.; Sinclair, K.; Kurz, D.; McNair, M.; Crist, S.; Shpritz, L.; Fitton, L.; Saffouri, R.; et al. Environmental and Economic Costs of Soil Erosion and Conservation Benefits. Science 1995, 267, 1117-1123. [CrossRef]

3. Lal, R. Soil Degradation by Erosion. Land Degredation Dev. 2001, 12, 519-539. [CrossRef]

4. Pérez-Soba, M.; Petit, S.; Jones, L.; Bertrand, N.; Briquel, V.; Omodei-Zorini, L.; Contini, C.; Helming, K.; Farrington, J.H.; Mossello, M.T.; et al. Land Use Functions-A Multifunctionality Approach to Assess the Impact of Land Use Changes on Land Use Sustainability. In Sustainability Impact Assessment of Land Use Changes; Helming, K., Pérez-Soba, M., Tabbush, P., Eds.; Springer: Berlin/Heidelberg, Germany, 2008; pp. 375-404. ISBN 978-3-540-78647-4.

5. Tezcan, A.; Büyüktaş, K.; Akkaya Aslan, Ş.T. A Multi-Criteria Model for Land Valuation in the Land Consolidation. Land Use Policy 2020, 95, 104572. [CrossRef]

6. Asiama, K.O.; Bennett, R.M.; Zevenbergen, J.A. Land Consolidation on Ghana's Rural Customary Lands: Drawing from The Dutch, Lithuanian and Rwandan Experiences. J. Rural. Stud. 2017, 56, 87-99. [CrossRef]

7. Cay, T.; Ayten, T.; Iscan, F. Effects of Different Land Reallocation Models on the Success of Land Consolidation Projects: Social and Economic Approaches. Land Use Policy 2010, 27, 262-269. [CrossRef] 
8. Choumert, J.; Phélinas, P. Determinants of Agricultural Land Values in Argentina. Ecol. Econ. 2015, 110, 134-140. [CrossRef]

9. Niroula, G.S.; Thapa, G.B. Impacts and Causes of Land Fragmentation, and Lessons Learned from Land Consolidation in South Asia. Land Use Policy 2005, 22, 358-372. [CrossRef]

10. Jürgenson, E. Land Reform, Land Fragmentation and Perspectives for Future Land Consolidation in Estonia. Land Use Policy 2016, 57, 34-43. [CrossRef]

11. Grau, A.; Odening, M.; Ritter, M. Land Price Diffusion across Borders: The Case of Germany. Appl. Econ. 2018, 52, 5446-5463. [CrossRef]

12. Tomal, M.; Gumieniak, A. Agricultural Land Price Convergence: Evidence from Polish Provinces. Agriculture 2020, 10, 183. [CrossRef]

13. Pramudia, A.; Susanti, E.; Auranda, M. Analysis of Rainfall Data to Develop the Classification Criteria for Identifying AgroClimate Resources on the Field. IOP Conf. Ser. Earth Environ. Sci. 2021, 824, 012065. [CrossRef]

14. Agnihotri, I.; Punia, M.P.; Sharma, J.R. Spatiotemporal Analysis of Maximum and Minimum Temperature within a Basin: A Case Study of West-Flowing River Basin of Kutch, Saurashtra and Marwar, India. J. Indian Soc. O Remote Sens. 2021, 49, 1779-1786. [CrossRef]

15. Wahyudi; Pramudia, A.; Salman, D.; Agustian, A.; Zulkifli; Permanasari, M.N. Management of Crop Planting in the Dry Season 2020, an Adaptation to the Impact of Drought for Supporting the Food Security. IOP Conf. Ser. Earth Environ. Sci. 2021, 824, 012090. [CrossRef]

16. Morel, J.; Kumar, U.; Ahmed, M.; Bergkvist, G.; Lana, M.; Halling, M.; Parsons, D. Quantification of the Impact of Temperature, CO2, and Rainfall Changes on Swedish Annual Crops Production Using the APSIM Model. Front. Sustain. Food Syst. 2021, 5, 665025. [CrossRef]

17. Andert, S.; Ziesemer, A.; Zhang, H. Farmers' Perspectives of Future Management of Winter Oilseed Rape (Brassica napus L.): A Case Study from North-Eastern Germany. Eur. J. Agron. 2021, 130, 126350. [CrossRef]

18. Trnka, M.; Brázdil, R.; Balek, J.; Dubrovský, M.; Eitzinger, J.; Hlavinka, P.; Chuchma, F.; Možný, M.; Prášil, I.; Růžek, P.; et al. Observed Changes in the Agroclimatic Zones in the Czech Republic between 1961 and 2019. Plant Soil Environ. 2021, 67, 154-163. [CrossRef]

19. Helbing, G.; Shen, Z.; Odening, M.; Ritter, M.; Helbing, G.; Shen, Z.; Odening, M.; Ritter, M. Estimating Location Values of Agricultural Land. Ger. J. Agric. Econ. 2017, 984, 188-201. [CrossRef]

20. Reydon, B.P.; Plata, L.E.A.; Sparovek, G.; Goldszmidt, R.G.B.; Telles, T.S. Determination and Forecast of Agricultural Land Prices. Nova Econ. 2014, 24, 389-408. [CrossRef]

21. Deaton, B.J.; Vyn, R.J. The Effect of Strict Agricultural Zoning on Agricultural Land Values: The Case of Ontario's Greenbelt. Am. J. Agric. Econ. 2010, 92, 941-955. [CrossRef]

22. Huang, H.; Miller, G.Y.; Sherrick, B.J.; Gómez, M.I. Factors Influencing Illinois Farmland Values. Am. J. Agric. Econ. 2006, 88, 458-470. [CrossRef]

23. Guiling, P.; Brorsen, B.W.; Doye, D. Effect of Urban Proximity on Agricultural Land Values. Land Econ. 2009, 85, 252-264. [CrossRef]

24. Yakupova, N.M.; Kadochnikova, E.; Beilin, I.L.; Makhmutovnaiskhakova, G. The Hedonic Model of the Land for Agricultural Purposes Market Value. Int. J. Emerg. Technol. 2019, 10, 210-213.

25. Bastian, C.T.; McLeod, D.M.; Germino, M.J.; Reiners, W.A.; Blasko, B.J. Environmental Amenities and Agricultural Land Values: A Hedonic Model Using Geographic Information Systems Data. Ecol. Econ. 2002, 40, 337-349. [CrossRef]

26. Garrod, G.D.; Willis, K.G. Valuing Goods' Characteristics: An Application of the Hedonic Price Method to Environmental Attributes. J. Environ. Manag. 1992, 34, 59-76. [CrossRef]

27. Ready, R.C.; Abdalla, C.W. The Amenity and Disamenity Impacts of Agriculture: Estimates from a Hedonic Pricing Model. Am. J. Agric. Econ. 2005, 87, 314-326. [CrossRef]

28. OECD. Taxation in Agriculture; OECD: Paris, France, 2020; ISBN 978-92-64-85165-8.

29. Podhrázská, J.; Kučera, J.; Karásek, P.; Konečná, J. Land Degradation by Erosion and Its Economic Consequences for the Region of South Moravia (Czech Republic). Soil Water Res. 2016, 10, 105-113. [CrossRef]

30. Szturc, J.; Hybler, V. The Impact of Updated Soil Properties on the Development of Land Price in Selected Cadastral Area Near the Strongly Urbanized Areas. J. Ecol. Engeneering 2019, 20, 161-168. [CrossRef]

31. Mašát, K. Výzkumný ústav meliorací a ochrany pudy Praha; Cesko; Ministerstvo zemedelství. In Metodika Vymezování a Mapování Bonitovaných Pudne Ekologických Jednotek; Výzkumný Ústav Meliorací a Ochrany Pudy: Praha, Czech Republic, 2002; ISBN 978-80-238-9095-2.

32. Novotný, I.; Vopravil, J. Metodika Mapování a Aktualizace Bonitovaných Pudne Ekologických Jednotek: Bonitace Zemedelského Pudního Fondu; Výzkumný Ústav Meliorací a Ochrany Pudy: Praha, Czech Republic, 2013; ISBN 978-80-87361-21-4.

33. Slaboch, J.; Čechura, L. Land Pricing Model: Price Re-Evaluation Due to the Erosion and Climate Change Effects. Agris Line 2020, 12, 111-121. [CrossRef]

34. Ritter, M.; Hüttel, S.; Odening, M.; Seifert, S. Revisiting the Relationship between Land Price and Parcel Size in Agriculture. Land Use Policy 2020, 97, 104771. [CrossRef]

35. Vopravil, J.; Novotný, I.; Khel, T.; Hladík, J.; Jacko, K.; Papaj, V.; Vašků, Z.; Vrabcová, T.; Pírková, I.; Rožnovský, J.; et al. Půda a Její Hodnocení v ČR Díl II; 1 Vyd.; Výzkumný Ústav Meliorací a Ochrany Půdy, v.v.i.: Praha, Czech Republic, 2011; ISBN 978-80-87361-08-5.

36. Slaboch, J.; Malý, M.; Mach, J. New challenges within the evaluated soil-ecological units valuation in the czech republic. In Proceedings of the Trends and Challenges of Agrarian Sector, Prague, Czech Republic, 16-17 September 2020; Czech University of Life Sciences Prague Faculty of Economics and Management: Praha, Czech Republic, 2020.

37. Chuchma, F.; Středová, H. Discrepancy in Climatic Zoning of the Current Soil Productivity Evaluation System. Contrib. Geophys. Geod. 2015, 45, 255-268. [CrossRef] 
38. Funes, I.; Savé, R.; de Herralde, F.; Biel, C.; Pla, E.; Pascual, D.; Zabalza, J.; Cantos, G.; Borràs, G.; Vayreda, J.; et al. Modeling Impacts of Climate Change on the Water Needs and Growing Cycle of Crops in Three Mediterranean Basins. Agric. Water Manag. 2021, 249, 106797. [CrossRef]

39. Major, D.J.; McGinn, S.M.; Beauchemin, K.A. Climate Change Impacts on Corn Heat Unit for the Canadian Prairie Provinces. Agron. J. 2021, 113, 1852-1864. [CrossRef]

40. Flack-Prain, S.; Shi, L.; Zhu, P.; Rocha, H.R.; Cabral, O.; Hu, S.; Williams, M. The Impact of Climate Change and Climate Extremes on Sugarcane Production. GCB Bioenergy 2021, 13, 408-424. [CrossRef]

41. Charalampopoulos, I.; Polychroni, I.; Psomiadis, E.; Nastos, P. Spatiotemporal Estimation of the Olive and Vine Cultivations Growing Degree Days in the Balkans Region. Atmosphere 2021, 12, 148. [CrossRef]

42. Olivera-Guerra, L.; Quintanilla, M.; Moletto-Lobos, I.; Pichuante, E.; Zamorano-Elgueta, C.; Mattar, C. Water Dynamics over a Western Patagonian Watershed: Land Surface Changes and Human Factors. Sci. Total Environ. 2022, 804, 150221. [CrossRef]

43. Donovan, M. Modelling Soil Loss from Surface Erosion at High-Resolution to Better Understand Sources and Drivers across Land Uses and Catchments; a National-Scale Assessment of Aotearoa, New Zealand. Environ. Model. Softw. 2022, 147, 105228. [CrossRef]

44. Arunrat, N.; Sereenonchai, S.; Chaowiwat, W.; Wang, C. Climate Change Impact on Major Crop Yield and Water Footprint under CMIP6 Climate Projections in Repeated Drought and Flood Areas in Thailand. Sci. Total Environ. 2022, 807, 150741. [CrossRef] [PubMed]

45. ShouQin, Z.; Juan, L.; WeiPing, L.; ChaoFu, W. Engineering design parameters of farming plots construction and plot characteristics in hilly area: A case study of Chongqing. Sci. Agric. Sin. 2017, 50, 4558-4574.

46. Wu, P.; Chen, G.; Liu, F.; Cai, T.; Zhang, P.; Jia, Z. How Does Deep-Band Fertilizer Placement Reduce N2O Emissions and Increase Maize Yields? Agric. Ecosyst. Environ. 2021, 322, 107672. [CrossRef]

47. Zhang, L.; Huang, Y.; Rong, L.; Duan, X.; Zhang, R.; Li, Y.; Guan, J. Effect of Soil Erosion Depth on Crop Yield Based on Topsoil Removal Method: A Meta-Analysis. Agron. Sustain. Dev. 2021, 41, 63. [CrossRef]

48. van Wesemael, B.; Poesen, J.; de Figueiredo, T. Effects of Rock Fragments on Physical Degradation of Cultivated Soils by Rainfall. Soil Tillage Res. 1995, 33, 229-250. [CrossRef]

49. Wang, X.; Li, Z.; Cai, C.; Shi, Z.; Xu, Q.; Fu, Z.; Guo, Z. Effects of Rock Fragment Cover on Hydrological Response and Soil Loss from Regosols in a Semi-Humid Environment in South-West China. Geomorphology 2012, 151-152, 234-242. [CrossRef]

50. Kosmas, C.; Moustakas, N.; Danalatos, N.G.; Yassoglou, N. The Effect of Rock Fragments on Wheat Biomass Production under Highly Variable Moisture Conditions in Mediterranean Environments. Catena 1994, 23, 191-198. [CrossRef] 